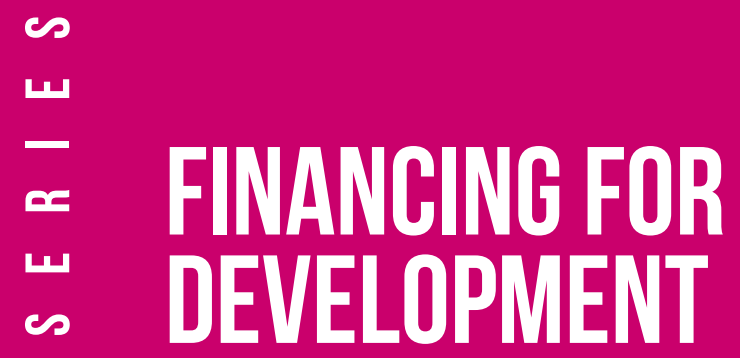

\title{
Latin America and
} the middle-income trap

Eva Paus

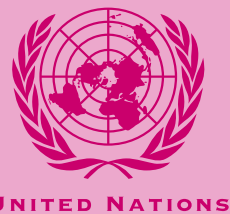

E C L A C 


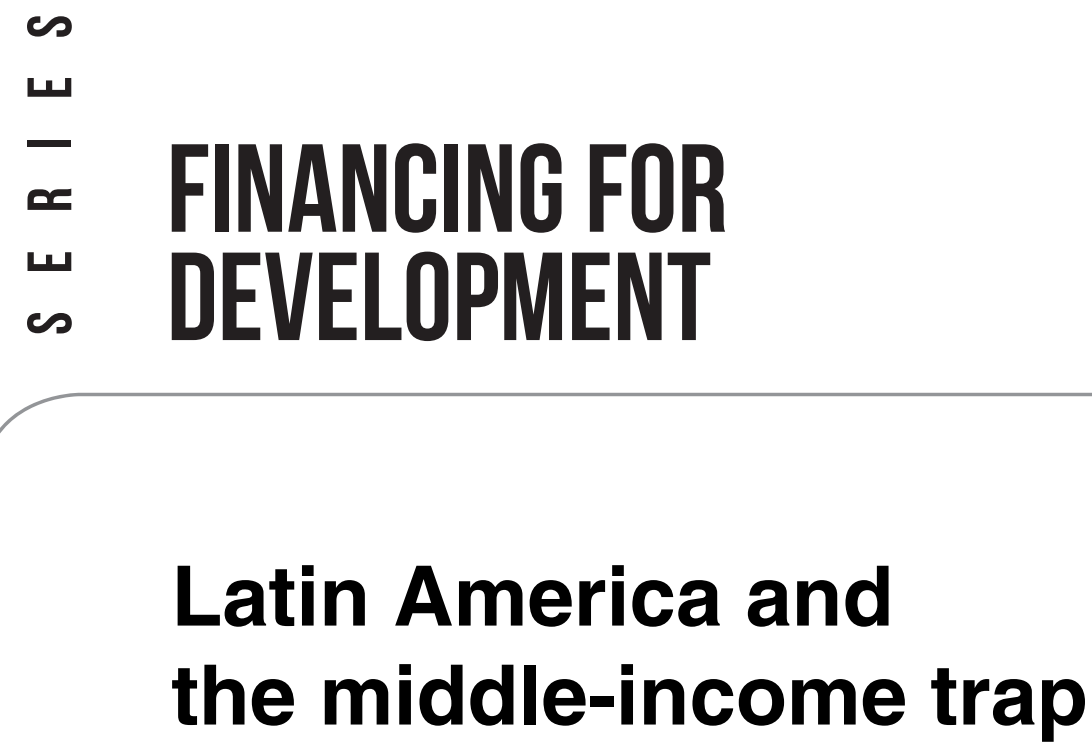

250

\section{Latin America and the middle-income trap}

Eva Paus

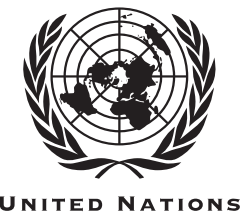

E C L A C 
This document has been prepared by Eva Paus, consultant of the Financing for Development Division, of the Economic Commission for Latin America and the Caribbean (ECLAC), and Professor of Economics and the Carol Hoffmann Collins, Director of the McCulloch Center for Global Initiatives at Mount Holyoke College, Massachusetts, United States of America.

The views expressed in this document, which has been reproduced without formal editing, are those of the authors and do not necessarily reflect the views of the Organization.

United Nations publication

ISSN 1564-4197

LC/L.3854

Copyright @ United Nations, June 2014. All rights reserved

Printed at United Nations, Santiago, Chile

Member States and their governmental institutions may reproduce this work without prior authorization, but are requested to mention the source and inform the United Nations of such reproduction. 


\section{Contents} 7

Introduction 9

I. The middle-income trap: a review of the literature

A. The middle-income trap: the structural change and productive capabilities gap 14

1. What you produce and export matters 14

2. The nature of structural change and the middle-income trap ........................................ 15

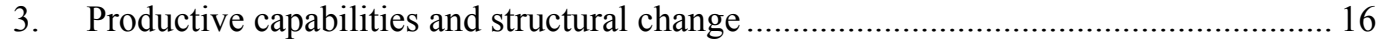

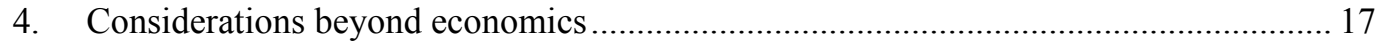

5. The critical role of government policies ……............................................................. 17

B. The middle-income trap: insufficient productive capabilities meet

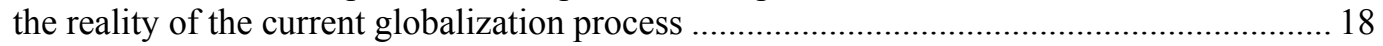

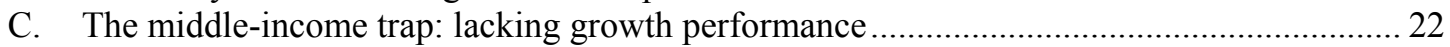

D. How we understand the middle-income trap makes a difference.......................................... 24

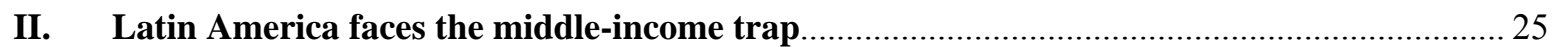

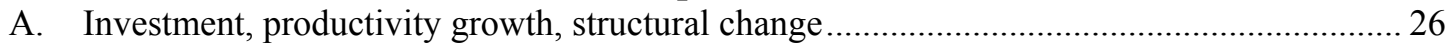

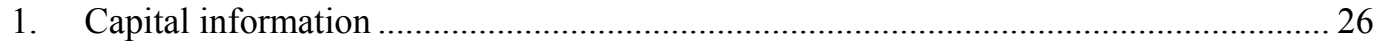

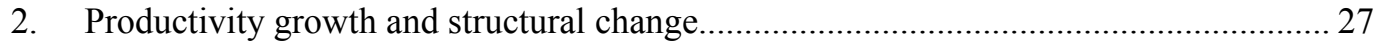

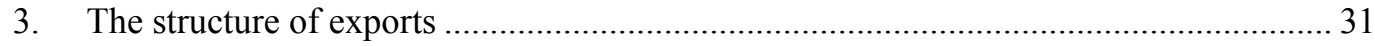

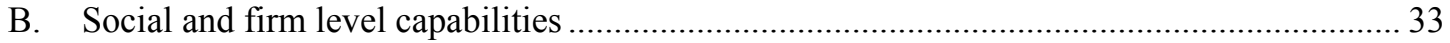

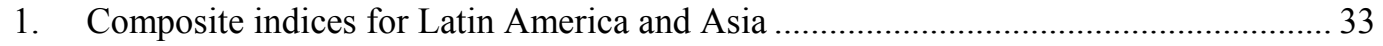

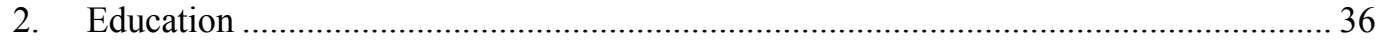

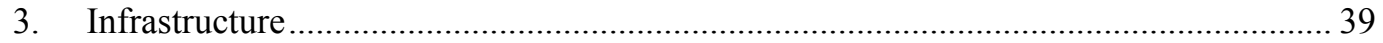

4. Firm level capabilities, with a focus on innovation .................................................... 42 


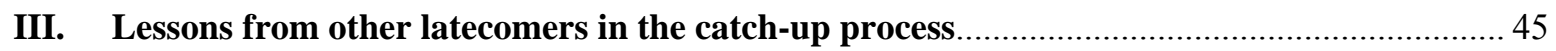

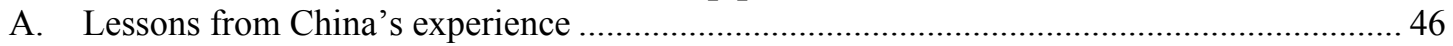

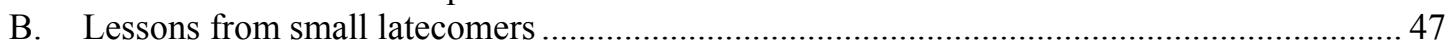

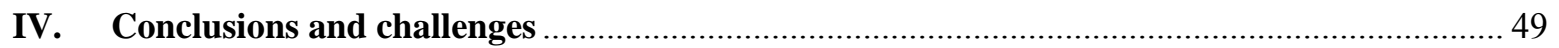

A. Cohesive productivist policies to address the structural heterogeneity in production ............ 49

B. Fiscal resources to support the advancement of social and firm level capabilities .................50

C. A cohesive incentive structure to support the advancement of local firm capabilities ..........51

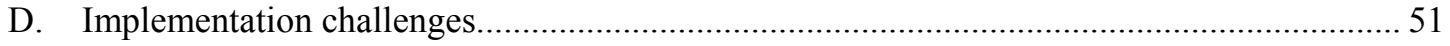

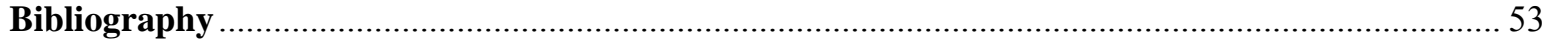

Financing for Development Series: issues published ….............................................................. 57

Tables

TABLE 1A LATIN AMERICA AND ASIAN COUNTRIES IN

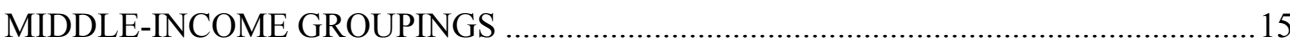

TABLE 1B LATIN AMERICA AND ASIAN COUNTRIES IN MIDDLE- INCOME GROUPINGS AND TRANSITIONS ………...................................16

TABLE 2

TABLE 3

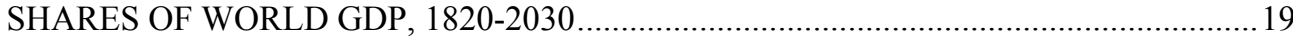

CHINA'S SHARE IN WORLD MANUFACTURED VALUE ADDED

IN FIVE FASTEST GROWING INDUSTRY SECTORS ................................................19

TABLE 4 MIDDLE-INCOME TRAP BASED ON GROWTH OUTCOMES .......................................22

TABLE 5 LATIN AMERICAN COUNTRIES IN THE MIDDLE-INCOME TRAP:

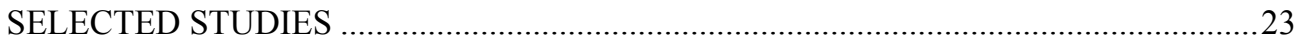

TABLE 6

TABLE 7

TABLE 8

TABLE 9

TABLE 10 GDP PER CAPITA GROWTH BYE REGION/INCOME GROUPING, 1971-2011 ..........25

GROSS FIXED CAPITAL FORMATION AS A SHARE OF GDP ……..........................2

DECOMPOSITION OF LABOR PRODUCTIVITY GROWTH, 1980s-2005 .....................22

DECOMPOSITION OF LABOR PRODUCTIVITY GROWTH INTO

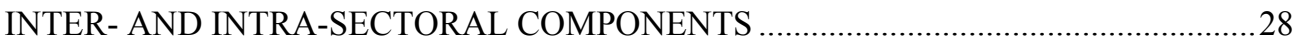

PERCENTAGE POINT CHANGE IN SECTORIAL EMPLOYMENT SHARES

IN LATIN AMERICAN COUNTRIES DURING THE 2000s............................................30

TABLE 11

MANUFACTURING VALUE ADDED AS A SHARE OF GDP....................................... 32

TABLE 12

TABLE 13

TABLE 14

TABLE 15

TABLE 16

RANKINGS OF LATIN AMERICAN AND SELECTED ASIAN MIDDLE- INCOME

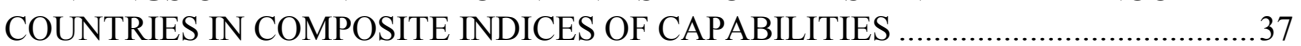

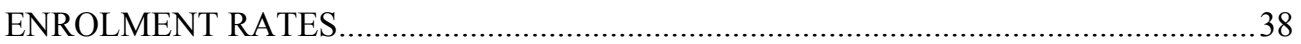

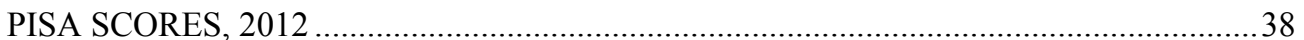

DOCTORAL DEGREES, 2008 OR MOST RECENT YEAR …………………................39

PUBLIC AND PRIVATE INVESTMENT IN INFRAESTRUCTURE IN

LATIN AMERICA AS A SHARE OF GDP, 1981-2006 ...............................................40

TABLE 17

TABLE 18

TABLE 19

TABLE 20

SPENDING ON INFRAESTRUCTURE AS A SHARE OF GDP, 1992-2011 ...................40

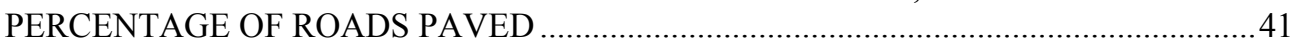

MOBILE PHONE AND INTERNET USERS (PER 100 PEOPLE), 2010.........................41

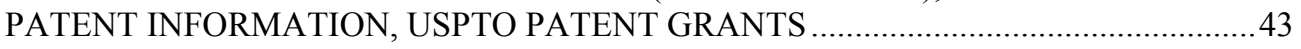

TABLE 21

PATENT APPLICATIONS

Figures

FIGURE 1

FIGURE 2A

CHINA'S SHARE IN WORLD IMPORTS.

GDP P.C. OF MIDDLE-INCOME COUNTRIES EXCLUDING

CHINA RELATIVE TO HIGH-INCOME OECD AND CHINA.

FIGURE 2B

GDP P.C. OF LATIN AMERICA AND THE CARIBBEAN RELATIVE

TO CHINA AND HIGH-INCOME OECD

FIGURE 3

GROSS FIXED CAPITAL FORMATION AS A SHARE OF GDP.

.26

FIGURE 4

DECOMPOSITION OF EXPORTS BY TECHNOLOGY INTENSITY:

SOUTH AMERICAN COUNTRIES AND CHINA.... 
FIGURE 5 DECOMPOSITION OF EXPORTS BY TECHNOLOGY INTENSITY: CENTRAL AMERICAN COUNTRIES, MEXICO, AND THE DOMINCAN REPUBLIC ..................32

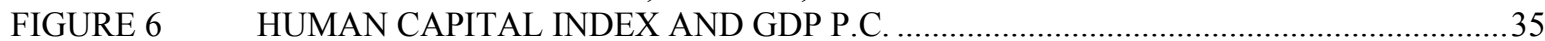

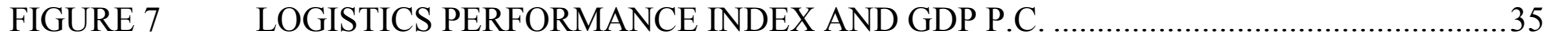

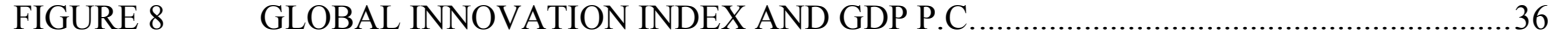

FIGURE $9 \quad$ R\&D INTENSITY IN MIDDLE-INCOME COUNTRIES, 2007.................................42

\section{Boxes}

BOX 1 COMPOSITE INDICES OF COMPETITIVENESS, STRUCTURAL CHANGE, AND SOCIAL CAPABILITIES 



\section{Abstract}

Promising economic growth during the 2000s obfuscates the reality that Latin American countries are facing the acute threat of a middle-income trap. In a review of the literature on the middle-income trap I distinguish two approaches to the middle-income trap: one focuses mainly on the lack of structural change, the driving forces behind it, and the national and global context in which it unfolds; the other stresses growth slowdowns irrespective of time and place. I offer an extension of the structural change approach with an emphasis on the implications of the current globalization process. A productive capabilities-focused analysis reveals serious gaps in social and firm-level capabilities in Latin America economies, though the magnitude differs across indicators and countries. The experiences of China and small latecomers trying to move from the middle to the high-income level (Chile, the Dominican Republic, Jordan, Ireland, and Singapore) suggest that a cohesive productive capabilities-focused development strategy holds out great promise for generating growth-enhancing structural change. I conclude with a discussion of the key challenges Latin American countries have to overcome for the successful implementation of such a strategy to avoid the middle-income trap.

JEL classification: 01; 054; 014; 025.

Key words: middle-income trap; Latin America; productive capabilities-focused approach; globalization; China 



\section{Introduction}

\section{A. The middle-income trap: insufficient productive capabilities meet the realities of globalization}

Latin American economies have done rather well during the 2000s. They reversed the long trend of income divergence with high-income countries, and they recovered much better from the global crisis than Japan, the US, and the EU. But the encouraging trends obfuscate the reality that Latin American countries are facing serious development challenges and that the current globalization process has heightened the urgency to address them.

There are many reasons why countries may grow for a certain period, e.g. a commodity price boom, influx of remittances, or access to outside financing. Indeed, all these factors played a role in the growth of Latin American economies in the 2000s. But growth can only be sustained in middle-income countries, if the driver of economic activity shifts from commodity production to the production of more sophisticated activities. This productive transformation is at the heart of the transition from middleincome to high-income status. A few countries have achieved this transformation, most notably the Asian Tigers. But Latin American countries - like middle-income countries in other regions - continue to wrestle with the challenge.

Moving from factor-driven to innovation-driven growth has always been the key challenge for middle-income countries. Yet it is only in the last few years that analysts have raised the specter of middle-income countries actually becoming trapped. The 'middle-income trap' refers to a situation where a middle-income country can no longer compete internationally in standardized, labor-intensive commodities because wages are relatively too high, but it can also not compete in higher value added activities on a broad enough scale because productivity is too low.

At the heart of the middle-income trap is the insufficient development of productive capabilities in a global context where the pressures to innovate have been rising relentlessly. Over the last 20 years, global competition has intensified considerably, product cycles have become shorter, and technological change has accelerated. Governments in developed countries have contributed and responded to these developments by putting ever greater emphasis on the promotion of research and development (R\&D) and innovation, thus raising the pressure on middle-income countries to follow suit. The predicament for 
middle-income countries has been greatly exacerbated by the fact that China, a middle-income country itself, has been leapfrogging in the innovation process with unprecedented speed and has become a fierce competitor in high-tech as well as low-tech goods.

The threat of the middle-income trap is real, but it is not inevitable that countries get stuck in it. Policy choice matters! It has played an important role in the insufficient development of productive capabilities, and it points the way towards overcoming the trap. Under the Washington Consensus regime, excessive reliance on market forces did not generate the productive capabilities needed for sustained growth. A coherent development strategy focused on the advancement of the requisite social and firm-level capabilities for greater innovation offers the greatest promise for overcoming the middleincome trap. If countries do not succeed in advancing innovation capabilities, their international competitiveness will end up being based on declining wages. That is clearly not desirable, but it is the default route. That is a key implication of the middle-income trap. And in that sense, a focus on the middle-income trap is a call for concerted action.

This paper is organized as follows. In Section I, provide a review of the current literature on the middle-income trap. I group the writings broadly into two approaches. One group of writers focuses mainly on the lack of structural change, the driving forces behind it, and the national and global context in which it unfolds. The other focuses primarily on growth slowdowns irrespective of time and place, and analyses tend to be based on neoclassical growth models or panel-based regression analysis. The analysis in the first group, which I extend with a more explicit focus on the implications of the current globalization process, emphasizes the importance of internal as well as external factors in explaining the middle-income trap. The second group concentrates on internal causal factors only. Authors in both groups highlight the role of government policies in improving social capabilities, especially education and infrastructure that support and enable more knowledge-intensive activities. But the writers who focus on firm learning and growth-enhancing structural change also tend to stress the importance of targeted productivist policies, broadly defined.

In Section II, discuss the state of Latin American economies vis-à-vis the middle-income trap. Latin America does not hold up well in cross-regional comparisons of productivity growth performance and indicators of social and firm level capabilities for greater incorporation of innovation. There are considerable gaps with other middle-income countries, especially in Asia, and particularly with China. There are also considerable gaps within countries themselves. This structural heterogeneity - highlighted by ECLAC (2010) and Pages-Serra (2010) among others - is a critical reality in Latin American economies that policy making has to address.

Nonetheless, the aggregate data obscure differences among Latin American countries. The findings underscore the argument in ECLAC (2012) that Latin American countries rank rather differently depending on the measure used, and that criteria other than income level are important for assessing an economy's well-being. A country like Brazil, for example, that has accumulated already a larger stock of capabilities for innovation than other Latin American countries is, theoretically, better positioned to avoid the middle-income trap. Yet that potential will not translate into reality if particular infrastructure gaps or inequality gaps become the binding constraint.

Section III summarizes insights from the experiences of other development latecomers in their attempts to move from the middle to the high-income level. I include the largest and most successful middle-income country, China, on the one hand, and several small latecomers working under liberal international economic policies on the other: Chile, the Dominican Republic, Jordan, Ireland, and Singapore. The evidence supports the argument in this paper that a cohesive capability-focused strategy can generate sustained economic growth. It also illustrates that lack of deliberate attention to capability advancement and to a conducive macro environment obstructs the achievement of growth-enhancing structural change. 
I conclude with a discussion of key challenges that Latin American countries have to overcome in the implementation of a productive capabilities-focused strategy. The specific policies for any particular country depend on the capability gap most constraining for that country's advancement towards greater innovation-incorporating production. Nevertheless there are four challenges that affect all Latin American countries to varying degrees: (1) the structural heterogeneity in production capabilities; (2) financing for the advancement of social and firm-level capabilities; (3) an incentive structure conducive to the advancement of local firm capabilities; and (4) the political and institutional capacity to implement a capability-focused strategy. The most vexing challenge may be the disjuncture between the slow process of firm learning and the implementation of capability-enhancing policies on the one hand and the relentless global pressures to compete on the basis of innovation on the other. 



\section{The middle-income trap: a review of the literature}

Middle-income countries comprise a heterogeneous group of countries. According to the World Bank there were 103 middle-income economies in 2012, with GNI p.c. ranging from $\$ 1,035$ to $\$ 12,616$. There were 48 lower middle-income countries (countries with a GNI p.c. below $\$ 4,085$ ) and 55 upper middle-income countries. The wide income range suggests considerable differences across countries, not only in GNI p.c. levels, but also in the productive capabilities needed for structural transformation to move to a high-income level.

Irrespective of theoretical framework and terminology, analysts tend to agree that the advancement from a middle-income to a high-income economy involves the internalization of innovation-incorporating activities on a significant scale. But they differ in their definition of a middleincome trap, in the reasons for it, and in the policy recommendations to avoid it. I group the writings on the subject into two broad groups.

For one group of analysts, the key characteristic of the middle-income trap is the lack of structural change towards higher value added activities in the context of international competitiveness. As such they are considering external factors in addition to internal factors behind the middle-income trap, though some are more explicit about it than others. Some writers focus on the nature of structural change in middle-income countries; others discuss the underlying capabilities needed to achieve growthenhancing structural change; and yet others broaden the discussion beyond the economic realm to include political and political economy factors. I expand the approach to incorporate explicitly the implications of today's globalization process for the competitive pressures that middle-income countries are facing. A number of writers do not discuss the reasons for the insufficient structural change directly. But their call for more pro-active and targeted policies to achieve growth-enhancing structural change makes clear that the absence of such policies has been an explanatory factor in countries confronting the middle-income trap.

For a second group of writers, the key characteristic of the middle-income trap is a slow-down in growth. Most authors in this group embrace, implicitly or explicitly, a neoclassical growth model. That implies, among other things, that specificities of time and location do not matter. By equating growth slowdowns with a middle-income trap authors identify exactly which countries face(d) this predicament. 
Several authors use panel data to explore the factors behind growth slowdowns empirically. They include different independent variables, and the policy implications of the regression results are not very clear.

In the 'structural change approach', there is a clear connection between the nature of structural change and economic growth. Authors argue there are many reasons why economies may grow for a while, but that only structural change towards higher productivity activities can provide a solid basis for sustained growth and increased living standards. In the 'growth slowdown' approach, on the other hand, structural change does not figure centrally, if at all, and growth may slow down for a whole variety of reasons.

The policy implications of the two approaches are different as well. The 'structural change approach' calls for more active and coordinated government policies for capability development. I argue that the current globalization process has increased the urgency for such actions. The 'growth slowdown approach' tends to suggest policies to advance education and infrastructure, especially related to information and communication technology.

\section{A. The middle-income trap: the structural change and productive capabilities gap}

Following Gill and Kharas who first coined the term 'middle-income trap' in 2007, one group of writers understands the middle-income trap as a situation where a middle-income country can no longer compete internationally in standardized, labor-intensive commodities because wages in the country are relatively too high, but it can also not compete in higher value added activities on a significant scale, because productivity is too low (Jankowska et al. 2012; Foxley 2012; Kuroda 2010; Lee 2013; Lin and Treichel 2012; Ohno 2009; Paus 2013, 2012a; World Bank 2010). Insufficient structural transformation is seen as the proximate cause of the middle-income trap.

\section{What you produce and export matters}

The analytical assumptions behind this understanding are those of structuralist economics, both of the old and the new variety. Different activities have different potential to generate technological spillovers, are characterized by different returns, and face different demand elasticities. As a result, economic development is a process where production is shifted increasingly towards activities with greater technological spillovers, increasing returns and higher demand elasticities, within and across sectors. Structural change is seen as the driver of growth for middle-income countries, not as a byproduct (Lin 2012, McMillan and Rodrik 2011, Rodrik 2011, Cimoli, Dosi, Stiglitz 2009, Ocampo, Rada, Taylor 2009, Ocampo and Vos 2008, Hausman, Hwang and Rodrik 2007, Shapiro and Taylor 1990).

There is ample empirical evidence that industrial upgrading and diversification lead to higher economic growth during the catch-up phase. Hausman, Hwang and Rodrik (2007) show a strong positive link between export sophistication and subsequent economic growth for countries across all income groups. When they investigate this relationship for different income groups separately, it does not hold for high-income and low-income countries, but it is highly significant for the middle-income group. In other words, cross-country differences in export sophistication are a distinguishing determinant of growth performance only among middle-income countries. Ocampo and Vos (2008) find a positive correlation between the change in the industrial output share and GDP p.c. growth. Imbs and Wacziarg (2003) establish a robust U-shaped relationship between GDP p.c. and production specialization, while Cadot, Carrère, and Strauss-Kahn (2009) find the same relationship between GDP p.c. and export concentration. And Cimoli, Porcile, and Rovira (2010) show that the income elasticity of demand for exports is higher for high-tech products than for low tech products. 


\section{The nature of structural change and the middle-income trap}

Growth-enhancing structural change should be reflected in greater diversification and upgrading of production. Jankowska et al. (2012) use the number of products a country exports with revealed comparative advantage as a measure of diversification and the level of sophistication of exported products (proxied by EXPY) as a measure for upgrading. They find that the two do not necessarily evolve jointly. In some countries and some periods the two have moved together (Brazil, Colombia, India, China). In other cases, they moved in stages: diversification without upgrading followed by upgrading without diversification (Mexico, Asian NICs). And in some cases they find that there has been diversification with downgrading (Argentina, Chile, and Peru).

Felipe et al. (2012) analyze historical transitions of countries that moved, between 1950 and 2010, from a lower-middle-income country (LMIC) to an upper-middle-income country (UMIC) and from an UMIC to a high-income country (HIC). They analyze eight indicators of structural transformation based primarily on revealed comparative advantage (RCA), the sophistication of the export basked, and the potential for structural change (using the PATH measure developed by Hidalgo et al. 2007). The authors find that the countries that graduated to upper-middle income or high-income status during 1950-2010, had "in general, more diversified, sophisticated, and non-standard export baskets at the time they were about to make the jump" than the countries that continue in the middle-income group (p. 46).

Felipe et al. also suggest a way to identify whether a country is in the middle-income trap, based on the number of years it has been in a particular income group relative to the median number of years of those countries that advanced to a higher-income level. They do not provide an economic rationale for this rather arbitrary criterion. Indeed, the nine countries that graduated from LMIC to UMIC after 1950 varied considerably in the number of years they spent as a LMIC, ranging from a low of 17 years for China to a high of 54 years for Costa Rica. And countries that had graduated from UMIC to HIC had been an UMIC for as short a period as seven years (Hong Kong, South Korea, Taiwan) and as long as 40 years (Argentina). Nonetheless, the analysis of Felipe et al. makes clear that many Latin American countries have been in the middle-income category for a long time (see table 1A).

TABLE 1A

LATIN AMERICAN AND ASIAN COUNTRIES IN MIDDLE-INCOME GROUPINGS

\begin{tabular}{lclc}
\hline Remained LMIC & $\begin{array}{c}\text { Number of years } \\
\text { in Country Group } \\
\text { until } 2010\end{array}$ & Remained UMIC & $\begin{array}{c}\text { Number of years } \\
\text { in Country Group } \\
\text { until 2010 }\end{array}$ \\
\hline Cambodia & 6 & China & 2 \\
India & 9 & Thailand & 7 \\
Indonesia & 25 & Malaysia & 15 \\
Myanmar & 7 & Uruguay & 15 \\
Pakistan & 6 & Venezuela (Bolivarian & 60 \\
Philippines & & Costa Rica & 5 \\
Sri Lanka & 34 & Mexico & 8 \\
Vietnam & 28 & & \\
Bolivia (Plurinational State of) & 9 & & \\
Brazil & 45 & & \\
Colombia & 53 & & \\
Dominican Republic & 61 & & \\
Ecuador & 38 & & \\
El Salvador & 58 & & \\
Guatemala & 47 & & \\
Jamaica & 60 & & \\
Panama & 56 & & \\
Paraguay & 56 & & \\
Peru & 38 & & \\
\hline
\end{tabular}

Source: Felipe et al. (2012). 
TABLE 1B

LATIN AMERICAN AND ASIAN COUNTRIES IN MIDDLE-INCOME GROUPINGS AND TRANSITIONS

\begin{tabular}{lccc}
\hline $\begin{array}{l}\text { From LMIC to UMIC } \\
\text { after 1950 }\end{array}$ & $\begin{array}{c}\text { Number of years in LMIC } \\
\text { before becoming UMIC }\end{array}$ & $\begin{array}{l}\text { From UMIC to HIC } \\
\text { after 1950 }\end{array}$ & $\begin{array}{l}\text { Number of years in UMIC } \\
\text { before becoming HIC }\end{array}$ \\
\hline China & 17 & Hong Kong & 7 \\
Malaysia & 27 & South Korea & 7 \\
South Korea & 19 & Singapore & 10 \\
Taiwan & 19 & Taiwan & 7 \\
Thailand & 28 & Argentina & 40 \\
Costa Rica & 54 & Chile & 13 \\
\hline
\end{tabular}

Source: Felipe et al. (2012).

\section{Productive capabilities and structural change}

Several authors suggest that the lack of broad structural change towards more sophisticated activities is the result of insufficient accumulation of productive capabilities towards greater innovation. Firm learning and the factors that enable and support it are central in some studies (Lee 2009, Ohno 2009, Paus 2013, 2012), while others focus on enabling factors more broadly without paying attention to firm learning (Jankowska et al. 2012, Lin and Treichel 2012, Lin 2012). While the terminology often differs across authors, but many of the ideas are similar.

Ohno (2009) argues that, in the catching-up industrialization process, firm learning advances through four stages. In the first phase, simple manufacturing develops under foreign guidance; in the second stage, supporting industries develop and technology transfer comes from importing, licensing, and FDI spillovers; in the third stage, domestic companies have mastered the technology and management to produce high-quality goods, and in the fourth stage, companies have moved to innovation and product design. Ohno defines the middle-income trap as the glass ceiling between stages 2 and 3 .

To understand structural change and upgrading outcomes, Paus (2012a) proposes a productive capabilities-based approach in the tradition of the literature on technological capability development with its emphasis on firm learning and the importance of time and place (Lall 1992, 2000, 2001; Cimoli, Dosi, Stiglitz 2009). She adds a particular emphasis on the opportunities and challenges offered by the current global environment. The productive capabilities-based approach analyzes the accumulation and interaction of social and firm level capabilities in the context of specific national and global characteristics. Social capabilities are the broadly-diffused capabilities that enable, complement, and push the advancement of firm-level capabilities. They have educational, infrastructural, institutional and organizational components (Abramovitz 1986). The development of local firm capabilities, as a collective ability for a critical mass of firms, comprises different aspects, all of which are aimed at innovating to raise value added. Such innovation includes improving quality and technological sophistication of existing products, producing new goods, and tapping new markets. Institutions, the broad set of rules and regulations governing the accumulation process, provide the support and incentive structure that allows and compels local firms to reach, collectively, a minimum capacity to absorb technology spillover and then move up the technology ladder.

Successful middle-income countries tend to exhibit three main traits: (1) many local firms have learned to adapt technological knowledge from more advanced countries to the firm and country-specific context through licensing and capital goods imports, and they have developed sufficient capabilities to absorb technology spillovers from TNC affiliates in the country; (2) outside of resource extraction, TNC affiliates have started to move away from the assembly of labor intensive, low-tech goods towards the production of medium and high-tech goods, though their activities may still be concentrated at the assembly stage; and (3) skills training programs and enrolments at the secondary school level have expanded considerably.

Moving to the next phase of capability accumulation requires the development of a national innovation system, with increasing enrolments at the tertiary level, more specialized technical skills, 
greater public expenditures on $\mathrm{R} \& \mathrm{D}$, and greater sophistication of the ICT infrastructure. The advancement of these social capabilities enables growing research and development activities by local firms (eventually towards more design) and a movement of TNC affiliates towards higher value added activities and some R\&D. When social and firm-level capabilities advance together and surpass a critical threshold, knowledge-intensive activities become a growing share of the productive sector.

Any sustained advancement of broad-based upgrading requires an interactive co-evolution of social and firm capabilities. If the different elements complement and reinforce each other, if they advance in a co-evolutionary way where they are part of a systemic whole, then the country can develop broad-based upgrading capabilities. However, if key institutions are missing, if policies are working at cross purposes, or if key complementary inputs are not developed (e.g. specific infrastructure elements or skills), then broad-based upgrading will be slowed or even blocked, and middle-income countries can get stuck.

Costa Rica offers an illustrative case of what can happen when social and firm level capabilities move out of synch over time (Paus 2014). During the ISI period (late1950s to 1980), social capabilities advanced to a remarkable level. Public education expenditures increased from 2.6 percent of GDP in 1960 to 6.2 percent in 1980. By the end of the period, primary school enrolment was universal and secondary school enrolment had doubled to 50 percent. In addition, health coverage expanded considerably as did the physical infrastructure. The high level of social capabilities was a key factor in Costa Rica's ability to attract foreign direct investment into electronics and medical devices during the 1990s. But under the new liberal economic model adopted in the 1980s the accumulation of social capabilities stalled and has seriously limited the ability of TNC affiliates to upgrade their activities in the country.

\section{Considerations beyond economics}

Most analysts focus primarily on economic forces. Foxley (2012), in contrast, expands the analysis to include social and political considerations. He defines the middle-income trap as the "difficulty to sustain economic growth above 5 percent for more than a decade while reducing inequality and consolidating and perfecting democratic institutions."(p.11)

Foxley highlights the existence of two other potential traps: the social and political instability trap and the institutional trap. He argues that a reduction in the highly unequal distribution of income and opportunities in many Latin American countries is critical for maintaining/achieving social and political peace. That, in turn, provides the needed foundation for a development strategy aimed at increasing productivity and diversifying exports.

While many economists tend to think of institutions as the rules and regulations governing accumulation, production decisions and distribution, Foxley, again, broadens the understanding to the social and political realm. He highlights serious institutional deficiencies in a number of Latin American countries brought to the fore by the inability to control the high incidence of crime and violence and the corruption in the management of natural catastrophes. He suggests that these deficiencies may be so severe as to constitute an institutional development trap.

\section{The critical role of government policies}

There is widespread agreement on the importance of private-public collaborations and partnerships for upgrading and sustained growth. In addition, many of the authors stress the critical role of pro-active government policies for the accumulation of productive capabilities. The pervasiveness of coordination failures and market inadequacies as well as the need for non-marginal changes call for deliberate government policies for the achievement of broad-based upgrading. Horizontal and vertical policies are needed to advance social capabilities, support the development of local firm capabilities and establish a critical level of absorptive capacity, enable TNC affiliates to upgrade production in the host country towards more sophisticated activities, and provide a set of economic incentives conducive to broadbased capability accumulation.

Lin $(2012,41)$ argues that "developing country governments play a key role in overcoming the issues of coordination and externality in the process of technological innovation, industrial upgrading, and structural change." And Ocampo et al. $(2009,114)$ state that "the state has to play a strong 
supportive role. Its available policy space has to expand so that countries can use instruments like sensible protection levels, targeted credit, and production subsidies to direct their limited resources towards productive ends."

Government policies have to expand education and infrastructure in a way that is in synch with, and sometimes in anticipation of, the advancement of firm level capabilities. Regarding research and innovation and the build-up of a national innovation system, the government plays a key role in establishing, enabling and promoting networks among public sector institutions, the academy and firms, in funding research and in providing incentives for private sector firms to move in that direction. Policies to support R\&D and inter-sectoral upgrading towards high-tech activities have to provide incentives for $\mathrm{R} \& \mathrm{D}$ and start-up funding for inventors who want to turn their ideas into profit-generating production.

Foxley (2012) emphasizes the importance of policies that address the high levels of income inequality in many Latin American countries, both for the direct benefit of the disadvantaged and for the political stability that greater equality will bring about. Fortunately social policies can generate win-win outcomes. Advancing access to quality education can enhance personal well-being and job prospects as well as provide support for structural change (Mkandawire 2013). And recent studies suggest that certain infrastructure investments have a positive impact on income distribution (CEPAL 2010).

One of the policy areas where analysts disagree is whether targeted policies to advance particular sectors should focus on developing new capabilities and comparative advantages in activities that are further apart in the Hausman-Klinger product space or that are closer together. Most economists in this group advocate the former, pointing to successful empirical examples (e.g., South Korea and China). Lin stands out in his advocacy for the latter.

\section{B. The middle-income trap: insufficient productive capabilities meet the reality of the current globalization process}

I expand the 'structural change approach' to the middle-income trap by contextualizing the insufficient development of productive capabilities for innovation in the specific context of the current globalization process. The main reason is that the lack of accumulation of the requisite innovation capabilities no longer only means that a middle-income country remains in the middle-income group for a longer period. Rather, globalization has increased the urgency for countries to compete to a greater extent on the basis of innovation or risk being left behind and face the threat of regression and declining living standards for a growing part of the population.

When China, India, and Central and Eastern European countries joined international markets in the 1990s, the global labor force doubled and competition intensified considerably (Freeman 2009). In addition, the creation and dissemination of knowledge has been advancing faster, as more countries compete in international markets, and the IT revolution drives the digitization of ever more tasks (Dahlmann 2009). Others identify the dominance of financial capital as a major driver behind more rapid change and the need for faster learning (Lundvall et al. 2002).

Developed country governments have contributed and responded to the faster technological change by beefing up measures to incentivize private sector spending in R\&D (see Deloitte 2012). For example, in the early 2000s, members of the European Union made greater research endeavors central to the EU's strategic efforts for growth. Their goal was to reach an R\&D intensity (research and development spending as a share of GDP) of 3 percent by 2010 (Kroll and Zenker 2009). This race to the top has increased the pressure on middle-income country governments to follow suit.

The rise of China has further intensified these pressures. Over the last decade or two, the Chinese government has implemented a variety of policies to support the indigenization of innovation activities. China has been emphasizing innovation at a much earlier point in the development process than other recent successful latecomers, i.e., the Asian Tigers.

With the rapid growth of China, and to a lesser extent India, over the last three decades, the sources of production and demand have started to shift (back) to the East. China's share in global GDP 
increased from 4.6 percent in 1973 to 16.8 percent in 2003 and is projected to reach nearly 25 percent by 2030. The numbers for India are 3.1, 6.1, and 10.4 percent, respectively (see table 2). During the 2000s, China's share in world manufactured value added in the five fastest growing sectors has increased dramatically. It reached nearly 50 percent in basic metals (see table 3 ).

TABLE 2

SHARES OF WORLD GDP, 1820-2030

\begin{tabular}{lrrrrr}
\hline Country/Area & 1820 & 1950 & 1973 & 2003 & 2030 \\
\hline Western Europe & 23.0 & 26.2 & 25.6 & 19.2 & 13.0 \\
United States & 1.8 & 27.3 & 22.1 & 20.7 & 17.3 \\
Australia, Canada, New Zealand & 0.1 & 3.4 & 3.3 & 3.1 & 2.5 \\
\hline West & 25.0 & 56.8 & 50.9 & 40.4 & 32.8 \\
\hline China & 32.9 & 4.6 & 4.6 & 16.8 & 23.8 \\
India & 16.0 & 4.2 & 3.1 & 6.1 & 10.4 \\
Japan & 3.0 & 3.0 & 7.8 & 6.1 & 10.4 \\
Other Asia & 7.4 & 6.8 & 8.7 & 13.6 & 15.4 \\
Latin America & 2.1 & 7.8 & 8.7 & 7.7 & 6.3 \\
Eastern Europe and former USSR & 9.0 & 13.1 & 13.8 & 6.1 & 4.7 \\
Africa & 4.5 & 3.8 & 3.4 & 3.2 & 3.0 \\
\hline Rest & 75.0 & 43.2 & 49.1 & 59.6 & 67.2 \\
\hline Asia as percentage of world & 59.3 & 14.9 & 24.2 & 42.6 & 53.3 \\
\hline
\end{tabular}

Source: Yusuf and Nabeshima (2010, Table 1.1, p.2) based on Maddison (2008).

TABLE 3

CHINA'S SHARE IN WORLD MANUFACTURED VALUE ADDED IN FIVE FASTEST GROWING INDUSTRY SECTORS

\begin{tabular}{lcc}
\hline $\begin{array}{l}\text { Leading producers in five fastest growing industry sectors } \\
\text { China's share in world MVA }\end{array}$ & 2000 & 2009 \\
\hline Office, accounting and computing machinery (ISIC 30): & 4 & 11 \\
Radio, television and communication equipment (ISIC 32) & 5 & 12 \\
Electrical machinery and apparatus (ISIC 31) & 8 & 33 \\
Other transport equipment (ISIC 35) & & 15 \\
Basic metals (ISIC 27) & 12 & 49 \\
\hline
\end{tabular}

Source: UNIDO 2011, 148.

In 2000, the year before it joined the WTO, China was the second largest exporter in the world. By 2009, the country had moved to the top spot accounting for nearly 10 percent of world exports. China's phenomenal export growth has increased competitive pressures in international markets considerably, for producers in developed and developing countries alike. Of equal, if not greater, importance for middle-income countries is the dramatic change in the composition of China's exports. Given China's size and abundance of cheap labor, it is not surprising that its share in world imports of low-tech goods increased significantly during the 2000s, from 19.6 percent in 2000 to 29.2 percent in 2011. What is astounding though is the growth of China's share in world imports of high-tech goods, from 6.7 percent in 2000 to 25.1 percent in 2011! As a result, middle-income countries now find themselves squeezed by China on both sides, in competition in standardized low-tech goods and in hightech products (see figure 1). 


\section{FIGURE 1}

\section{CHINA'S SHARE IN WORLD IMPORTS}

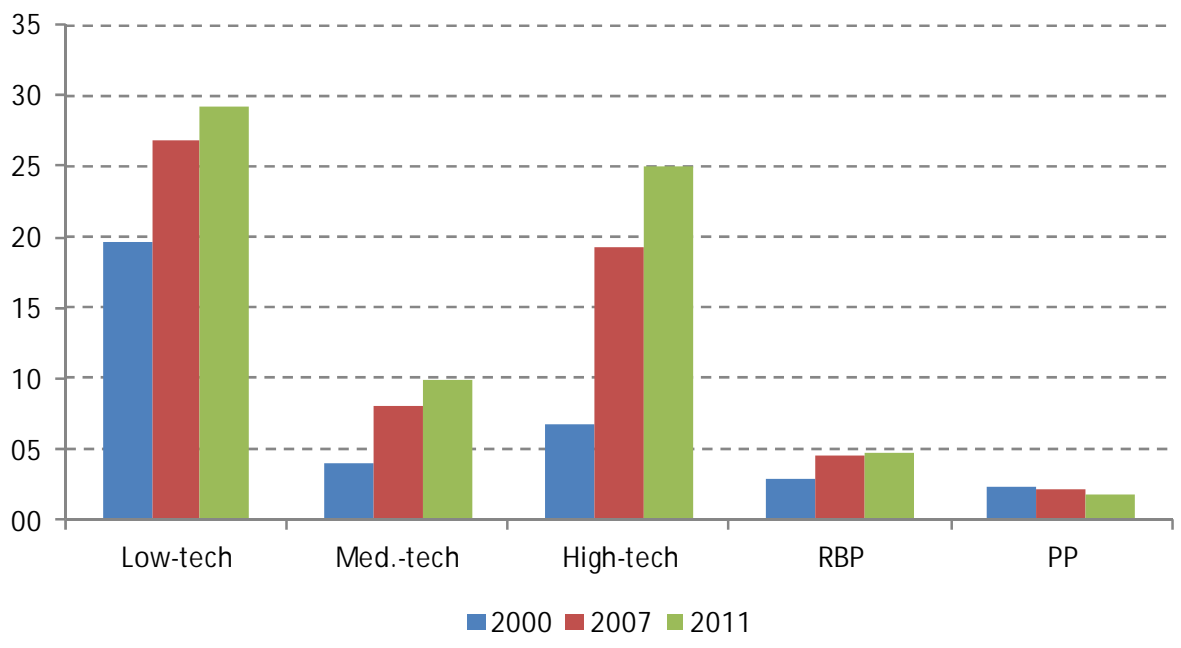

Source: Author's calculations based on UN-Comtrade.

China's performance does not conform with a widely-held belief among development economists that each development stage generally corresponds to a particular range on the GDP p.c. spectrum and a certain set of capabilities. In China, capability accumulation has surged ahead of its income level and development stage. Already in 2000, China's export basket was 3.5 times more sophisticated than predicted for its GDP p.c. level (Hausmann et al. 2007). And even though China's GDP p.c. today is still lower than that of many other upper middle-income countries in Latin America and elsewhere, the country's exports are competing in product markets that are crowding out and maybe pre-empting spaces for other middle-income countries attempting to move up the value chain into those spaces.

To be sure, as China is upgrading production and wages are rising, Chinese producers have been vacating some of the spaces in low-wage, standardized, labor-intensive production, even though there is still a large reserve army of low-wage workers in the interior of the country. But it is countries with lower wages that have been filling these spaces (e.g., Vietnam and Bangladesh), not countries with wages similar to or higher than those in China's main production areas. Indeed, Dinh et al. (2013) suggest that China's move up the value chain offers propitious opportunities for countries in SubSaharan Africa to expand employment and industrialization in light manufacturing.

The rise of China (and India) also has important implications on the demand side. The high economic growth and the rapidly expanding middle classes in these two large countries offer enormous market potential. Many Asian economies are tightly integrated into regional production networks, and China's rapid growth has been a principal driver behind the dynamic changes in the regional architecture of production (Yusuf and Nabeshima 2010). Natural resource exporters in Latin America and Sub Saharan Africa have benefitted greatly from the commodity price boom of the 2000 s which was driven - to a significant extent - by China's growth. But they have not been able to tap the potential of the Chinese market. That is partly due to China's protective practices, but mostly to countries' inability to compete in products that China is importing.

One of the implications of China's rapid economic growth and changing export structure is that many middle-income countries now face a dual divergence: on the one hand, vis-à-vis high-income countries (with the exception of the 2000s) and on the other hand vis-à-vis China (see figure 2A and 2B). The magnitude and speed of the decline in the income gap between Latin America and the Caribbean and China is particularly striking. Where LAC's GDP p.c. was 14.8 times higher than China's in 1980, it was 1. 4 times higher in 2012. The dual divergence is a critical challenge for middle-income countries today. 
FIGURE 2A

GDP P.C. OF MIDDLE-INCOME COUNTRIES EXCLUDING CHINA RELATIVE TO HIGH-INCOME OECD AND CHINA

(Constant 2005 PPP)

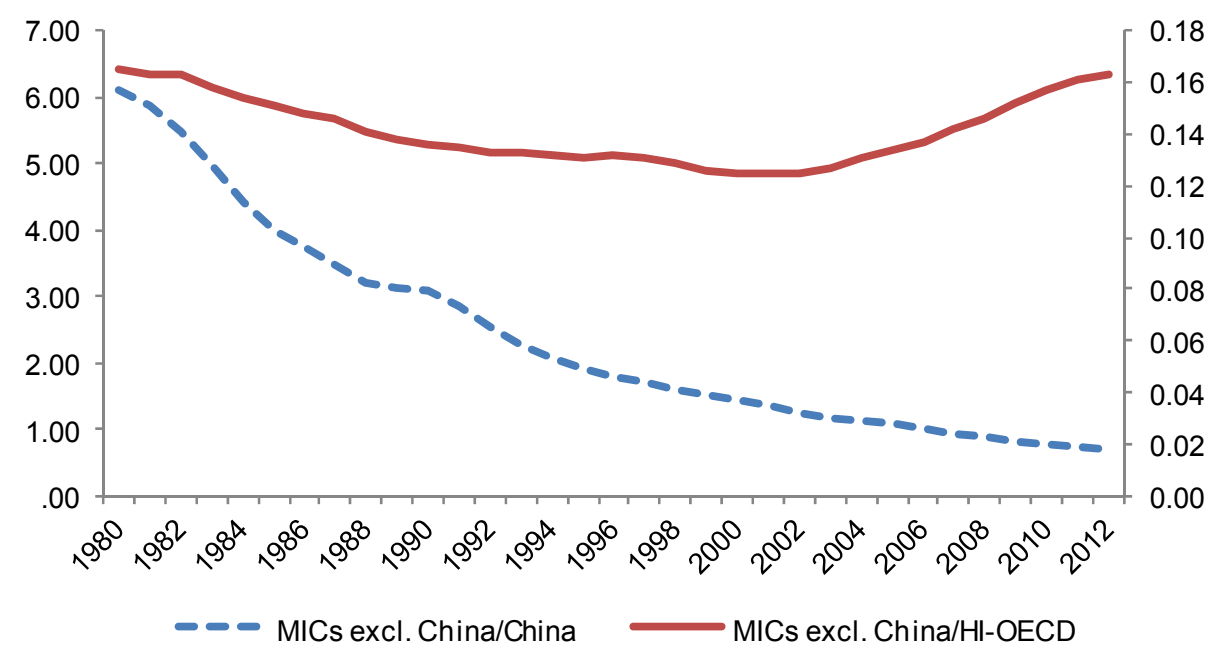

Source: Author's calculation based on World Development Indicators.

FIGURE 2B

GDP P.C. OF LATIN AMERICA AND THE CARIBBEAN RELATIVE TO CHINA AND HIGH-INCOME OECD

(Constant 2005 PPP)

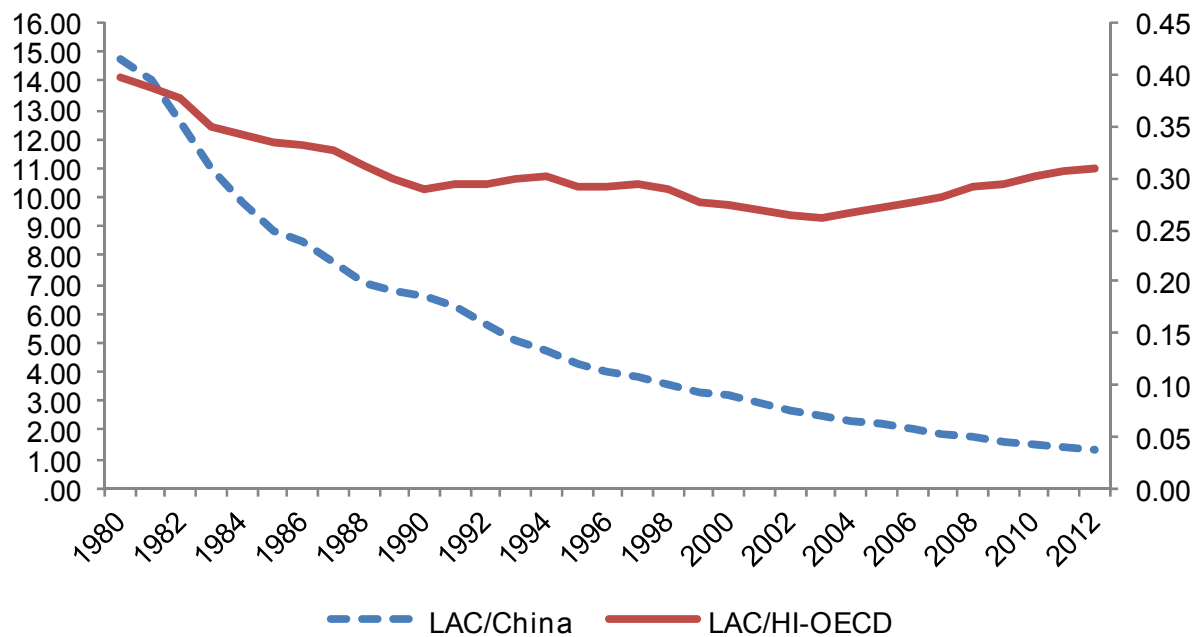

Source: Author's calculation based on World Development Indicators. 


\section{The middle-income trap: lacking growth performance}

A number of authors use the term 'middle-income trap' to describe inadequate growth outcomes in middle-income countries: some focus on growth slowdowns and others on lack of convergence. The authors identify a set of countries that are or have been in a middle-income trap, but they differ in the specific definition of the middle-income trap, the time period analyzed, the countries included in the empirical work, and the base year for purchasing power parity prices (see table 4).

TABLE 4

MIDDLE-INCOME TRAP BASED ON GROWTH OUTCOMES

\begin{tabular}{|c|c|c|c|c|}
\hline Author & $\begin{array}{l}\text { Definition of Undesirable } \\
\text { Growth Outcome }\end{array}$ & $\begin{array}{l}\text { GDP p.c. Boundaries for } \\
\text { Middle-income countries }\end{array}$ & $\begin{array}{l}\text { Prices for GDP } \\
\text { Calculation }\end{array}$ & Time Period \\
\hline Felipe et al (2012) & $\begin{array}{l}\text { Above average number } \\
\text { of years in middle- } \\
\text { income group }\end{array}$ & $\$ 2000-\$ 11750$ & 1990 PPP & $1950-2010$ \\
\hline $\begin{array}{l}\text { Eichengreen et al. } \\
\text { (2011) }\end{array}$ & Growth slowdown & $\$ 10000$ & $\begin{array}{l}2005 \text { const. int'l } \\
\text { prices }\end{array}$ & $1957-2007$ \\
\hline $\begin{array}{l}\text { Eichengreen et al. } \\
(2013)\end{array}$ & Growth slowdown & $\$ 10000$ & $\begin{array}{l}2005 \text { const. int'l } \\
\text { prices }\end{array}$ & $1957-2010$ \\
\hline Aiyar et al (2012) & Growth slowdown & Boundaries vary & $\begin{array}{l}2005 \text { const. int'l } \\
\text { prices }\end{array}$ & $1955-2009$ \\
\hline $\begin{array}{l}\text { Robertson and } \mathrm{Ye} \\
(2013)\end{array}$ & Lack of convergence & $\begin{array}{l}\text { Middle } 40 \% \text { of countries } \\
\text { ranked by PPP in } 2010 \\
\text { ( } 8 \%-35 \% \text { of US GDP p.c.) }\end{array}$ & $\begin{array}{l}2005 \text { const. int'l } \\
\text { prices }\end{array}$ & $1970-2007$ \\
\hline
\end{tabular}

Source: Author's own elaboration.

Eichengreen et al. $(2011,2013)$ argue that growth will inevitably slow down once an economy absorbs the agricultural surplus labor, gets closer to the technology frontier, and indigenous innovation becomes more important. The authors aim to identify the income level around which such slowdowns occur. They define a slowdown in growth as a period where seven years of at least 3.5 percent average annual growth are followed by seven years of average annual economic growth that is at least 2 percentage points lower. In the 2011 study, the income level at which growth slows down is around $\$ 16,000$; but in the 2013 study, there are two slowdown points, one around $\$ 10,000$ to $\$ 11,000$ and the other around $\$ 15,000$. The different outcomes, the authors argue, are due to the use of different data sets and time periods. The two studies concur only partially on which Latin American countries have been in a middle-income trap (see table 5).

Given that the study includes only countries with a GDP p.c. above $\$ 10,000$, many of the growth slowdowns occurred in today's developed countries: Australia, Austria, Belgium, Denmark, Finland, France, Israel, Ireland, Japan, South Korea, Netherlands, New Zealand, Norway, Singapore, Sweden, the UK, and the US. It is questionable that such a conceptualization tells us much about the challenges faced by middle-income countries today.

Starting from a Solow growth model Aiyar et al. (2013) estimate a predicted rate of growth for countries at different income levels. A country is defined as experiencing a growth slowdown if the residual (the actual minus the predicted growth rate) puts the country in the bottom quintile of residual changes between successive periods, and if there is a sustained slowdown. Based on these criteria they identify 123 slowdowns (out of 1,125 observations). They find that the frequency of slowdowns is disproportionately higher in middle-income countries, a result that is robust for different specifications for income boundaries. Thus, they conclude, middle-income countries are more likely to be trapped.

Robertson and Ye (2013) also start from the concept of income convergence. Using the US as the reference country, they characterize a country as being in the middle-income trap if the country's expected per capita income vis-à-vis the US remains invariant over time and if it lies within the middle-income band. 
Out of the 189 countries included in the study, 46 are middle-income countries, and 19 of them satisfy their definition of a middle-income trap. Seven of these are Latin American countries (see table 5).

Agènor and Canuto (2012) offer a mathematical model of the middle-income trap. It is a twoperiod overlapping generations model, with two types of labor (basic and advanced, i.e., with design capabilities) and two types of infrastructure (basic and advanced, i.e. ICT-based). Given the behavioral assumptions underlying the model, countries will end up in a steady state low growth trap, if investment in IT-based infrastructure is insufficient. However, the model assumes away some of the most vexing challenges in the upgrading process, i.e. there is no production sector and no firm learning.

TABLE 5

LATIN AMERICAN COUNTRIES IN THE MIDDLE-INCOME TRAP: SELECTED STUDIES

\begin{tabular}{|c|c|c|c|c|c|}
\hline & $\begin{array}{l}\text { Eichengreen } \\
\text { et al. (2011) }\end{array}$ & $\begin{array}{l}\text { Eichengreen } \\
\text { et al. (2013) }\end{array}$ & Aiyar et al. (2013) & $\begin{array}{l}\text { Robertson \& } \\
\text { Ye (2012) }\end{array}$ & $\begin{array}{l}\text { Felipe et al. } \\
(2012)\end{array}$ \\
\hline Argentina & 1970,1998 & & $1980-19851995-2000$ & & \\
\hline Belize & & & $1990-1995$ & & \\
\hline $\begin{array}{l}\text { Bolivia (Plurinational } \\
\text { State of) }\end{array}$ & & & $1975-1980$ & & LMIC trap \\
\hline Brazil & & & $1975-19801980-1985$ & & LMIC trap \\
\hline Chile & 1998 & & $1995-2000$ & & \\
\hline Colombia & & & & & LMIC trap \\
\hline Costa Rica & & & & $x$ & \\
\hline Dominican Republic & & & $1975-1980$ & & LMIC trap \\
\hline Ecuador & & & $1975-19801980-1985$ & $x$ & LMIC trap \\
\hline Guatemala & & & $1980-1985$ & $x$ & LMIC trap \\
\hline Guyana & & & $1980-1985$ & & \\
\hline Haiti & & & $1980-1985$ & & \\
\hline Honduras & & & $\begin{array}{l}1960-1965 \\
1980-1985\end{array}$ & $x$ & \\
\hline Jamaica & & & $\begin{array}{l}1970-1975 \\
1990-1995\end{array}$ & & LMIC trap \\
\hline Mexico & & 1981 & 1980-1985 & $x$ & \\
\hline Nicaragua & & & $\begin{array}{l}1965-1970 \\
1985-1990\end{array}$ & & \\
\hline Panama & & & $1980-1985$ & $x$ & LMIC trap \\
\hline Paraguay & & & $1980-1985$ & & LMIC trap \\
\hline Peru & & & $\begin{array}{l}1975-1980 \\
1980-1985\end{array}$ & $x$ & LMIC trap \\
\hline Puerto Rico & $1973,1988,2000$ & 1973,1988 & & & \\
\hline Trinidad \& Tobago & 1980 & 1982 & $\begin{array}{l}1960-1965 \\
1980-1985\end{array}$ & & \\
\hline Uruguay & 1998 & & $1995-2000$ & & UMIC trap \\
\hline $\begin{array}{l}\text { Venezuela (Bolivarian } \\
\text { Republic of) }\end{array}$ & 1974 & 1974 & $1975-1980$ & & UMIC trap \\
\hline
\end{tabular}

Source: Author's own elaboration.

One of the appeals of the studies discussed above is that they tell us exactly which countries are or have been in a middle-income trap. Nonetheless, there are good reasons for skepticism. First, the list of countries identified as being or having been in the middle-income trap is not robust across the different studies (see Table 5 for a listing of Latin American countries). That is not surprising in light of the different criteria and definitions, but it raises doubts about the usefulness of precision in this case. Second, it is not clear to what extent the inclusion of today's developed countries in the analysis advances our understanding of the specific challenges faced by middle-income countries in the current 
globalization process. The reasons for growth slowdowns may well differ over time. And choice of development strategy and policies matter for growth outcomes. It is hardly coincidental that more than two thirds of the growth slowdowns among the middle-income countries identified by Aiyar et al. occurred after 1980, when many of these countries had to deal with a severe foreign debt crisis and adopted Washington Consensus policies.

In the search of regularities in the factors behind growth slowdowns Eichengreen et al. (2013, 2011) find that a high investment ratio, an undervalued exchange rate and a high old age dependency ratio increase the likelihood of a growth slowdown. But nearly all the countries included in the analysis are today's developed countries. Aiyar et al. (2013) include 42 explanatory variables in seven different categories (institutions, demography, infrastructure, macro environment and policies, economic structure, trade structure and other) to estimate the likelihood of growth slowdowns. Eighteen variables turn out to be statistically significant. It is not clear, however, what these findings mean for policy making.

Aiyar et al. also conduct their econometric analysis only for the group of middle-income countries. They identify three variables that are only statistically significant in this group, but not for the whole sample with countries of all income levels. These are road networks, telephone lines, and the size of the government; all three variables enter with a negative coefficient.

\section{How we understand the middle-income trap makes a difference}

It makes a difference for policy makers whether they adopt the 'structural change approach' or the 'growth slowdown approach' to the middle-income trap. In the growth slowdown approach policy makers tend to worry less unless there is there is a slowdown in growth. But in the structural change approach, there is a distinct possibility for a disjuncture between income convergence and capability convergence. Income and capability convergence can coincide as they have in China during the last two decades. But income convergence can also be accompanied by capability divergence. That was the case in Ireland and Greece during the 2000s, and also in Latin America, as we will see in the next section. And when the two diverge, income convergence cannot be sustained.

Voices within and outside of China have raised concerns about whether China will be able to make the leap to innovation-driven growth or become stuck at the middle-income level (Zoellick 2011, Shanghai Daily 2011) But for all middle-income countries other than China, it is the very rise of China that is contributing to the threat of a "trap" at this juncture. From a structural change perspective, there is little to worry about a middle-income trap in China. After all, growth cannot be sustained at double digit levels forever But the rapid accumulation of productive capabilities, especially in the innovation area, provides a solid basis for sustained growth in the future, even if the rate itself is lower. 


\section{Latin America faces the middle-income trap}

This section explores how Latin America is faring vis-à-vis the middle-income trap. From a 'growth slowdown perspective,' the situation looks quite good. With the 'Lost Decade of the Eighties' and low growth during the Nineties, it is not surprising that most Latin American countries have been in the middle-income category for a long time (see table 5). But growth improved considerably during the fiveyear period of 2003 to 2007, i.e. the period between the recession in the early 2000s and the onset of the global crisis in 2008. For the first time in decades, Latin American economies started to narrow the income gap with high-income OECD countries.

Nonetheless, growth was still lower than in any of the other areas of late developers, with the exception of Sub-Saharan Africa (see table 6). Furthermore, it is highly unlikely that the higher growth during the quinquennium can be sustained in the future, as it was driven by favorable factors that were likely transitory (e.g., the commodity price boom)

TABLE 6

GDP PER CAPITA GROWTH BY REGION/INCOME GROUPING, 1971-2011

\begin{tabular}{cccccccc}
\hline & $\begin{array}{c}\text { East Asia } \\
\text { and Pacific }\end{array}$ & $\begin{array}{c}\text { Europe and } \\
\text { Central Asia }\end{array}$ & $\begin{array}{c}\text { High income: } \\
\text { OECD }\end{array}$ & $\begin{array}{c}\text { Latin America } \\
\text { and Caribbean }\end{array}$ & $\begin{array}{c}\text { Middle East } \\
\text { and North Africa }\end{array}$ & $\begin{array}{c}\text { South Asia } \\
\text { Sub-Saharan } \\
\text { Africa }\end{array}$ \\
\hline $1971-1980$ & 4.5 & $\ldots$ & 2.7 & 3.2 & 2.7 & 0.7 & 0.9 \\
$1981-1990$ & 5.7 & -1.7 & 2.7 & -0.8 & 0.2 & 3.0 & -0.9 \\
$1991-2000$ & 7.1 & -1.7 & 1.9 & 1.6 & 1.8 & 3.2 & -0.3 \\
$2003-2007$ & 9.3 & 7.4 & 1.9 & 3.7 & 3.3 & 6.6 & 3.0 \\
$2001-2011$ & 8.2 & 4.7 & 0.9 & 2.2 & 2.6 & 5.3 & 2.1 \\
\hline
\end{tabular}

Source: World Bank (2012) World Development Indicators and Global Finance. 
One of the key arguments in this paper is that growth can only be sustained over time if it is based on a broad shift of production to higher value added activities. From the' structural change perspective' of the middle-income trap, one would thus want to know about productivity growth in Latin America, about the nature of structural change in production as well as exports, and about the state of social and firm level capabilities, especially with respect to innovation-incorporating activities. It is beyond the scope of this paper to provide an in-depth analysis of all the variables involved. Instead I draw broad inferences from selected indicators, both for Latin America as a whole and for individual countries.

At the aggregate level, the performance of productivity, structural change, and key social and firm capabilities suggests that Latin America is in serious danger of becoming trapped at the middle-income level without a change in policies. But the country level data often show substantial heterogeneity, indicating that some countries are better positioned than others to avoid a middle-income trap.

\section{A. Investment, productivity growth, structural change}

\section{Capital formation}

Between 2000 and 2012, gross fixed capital formation in Latin America accounted, on average, for 19.5 percent of GDP, up from 18.5 percent during the 1990s. Yet the investment performance in the 2000 s was still below the average of the 1970s and 1980s. It was also below that of lower and upper middle-income countries and even of low-income countries (see table 7). For most Latin American countries, the investment ratio is still a far cry from the 25 percent investment ratio that the Spence Report identified as a threshold for sustained growth. Nonetheless, the aggregate number obscures the underlying heterogeneity across the region. The average investment ratio in the 2000s ranged from a low of around 15 percent in Paraguay, El Salvador, and Bolivia to a high of 25 percent in Nicaragua and Honduras (see figure 3).

FIGURE 3

GROSS FIXED CAPITAL FORMATION AS A SHARE OF GDP

(Average for 2000-2012)

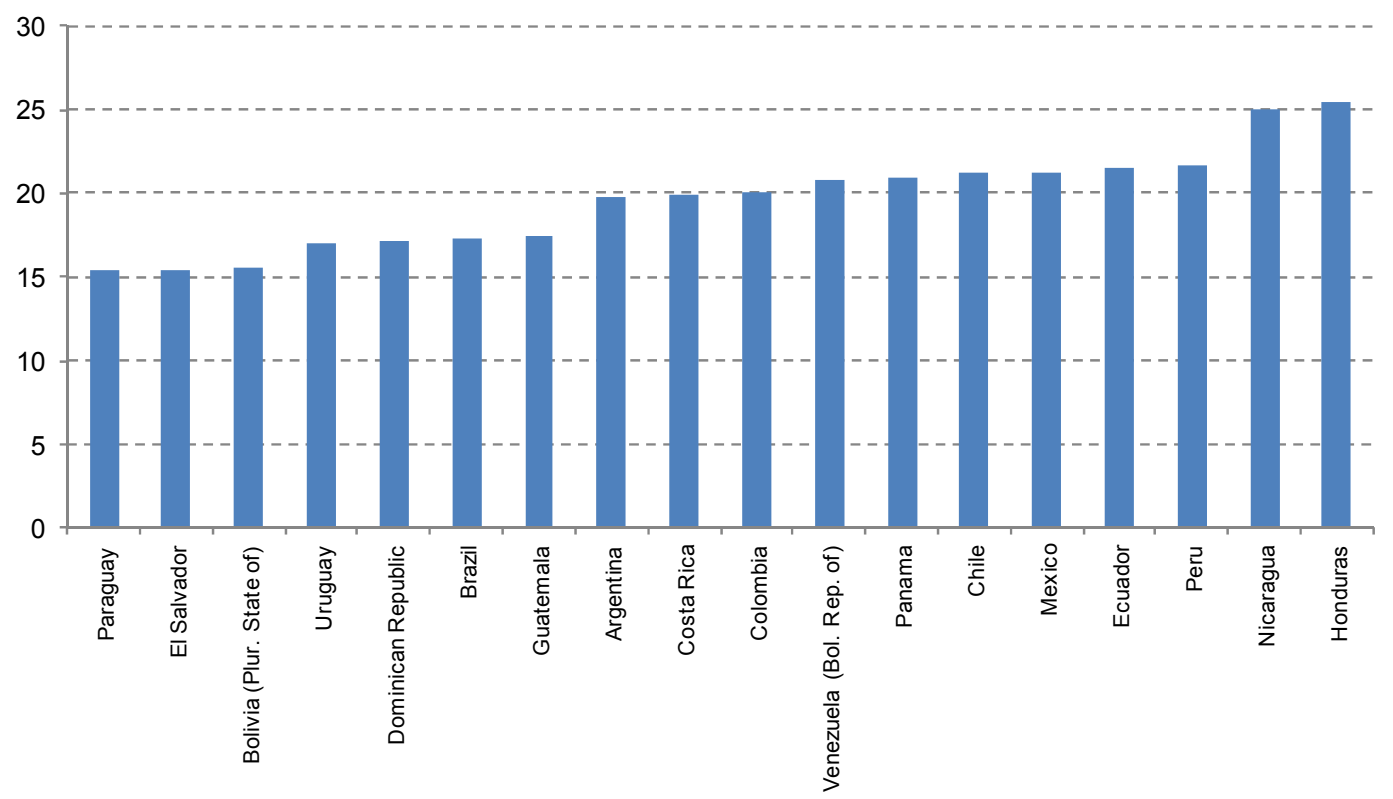

Source: Author's calculations based on World Development Indicators, on-line. 
TABLE 7

GROSS FIXED CAPITAL FORMATION AS A SHARE OF GDP

(Decade averages)

\begin{tabular}{lcccc}
\hline & $1970-1979$ & $1980-1989$ & $1990-1999$ & $2000-2012$ \\
\hline Developing East Asia and Pacific & 26.3 & 28.4 & 32.0 & 36.7 \\
Latin America and Caribbean & 21.2 & 20.1 & 18.5 & 19.5 \\
Lower middle-income countries & 17.0 & 21.1 & 22.9 & 24.4 \\
Upper middle-income countries & 24.3 & 24.7 & 25.3 & 28.1 \\
OECD members & 24.6 & 23.4 & 22.1 & 20.9 \\
Low-income countries & n.a. & 15.9 & 17.3 & 21.7 \\
\hline
\end{tabular}

Source: Based on World Development Indicators, on-line, accessed Dec 20, 2013.

Investment ratios alone do not tell the whole story. It matters whether investment increased in absolute terms and what its composition is. For the total of the 18 countries in Figure 3, gross fixed capital formation was 1.7 times higher in 2012 than in 2000 (measured in constant 2005 \$). In Nicaragua, it was 14.5 times higher, but in Honduras it was only 1.4 times higher. ECLAC data indicate that not all investment went to machinery and equipment. On average, more than half of the investment was in construction.

\section{Productivity growth and structural change}

The magnitude of productivity growth and the nature of structural change have been distinguishing factors in the performance of Asian and Latin American economies during the last two decades. In a widely cited study, McMillan and Rodrik (2011) show that, between 1990 and 2005, labor productivity growth was more than twice as large in developing Asia as in Latin America. The authors decompose labor productivity growth into productivity growth within sectors and productivity growth that results from the reallocation of labor across sectors (see table 8). They find that a major reason for the regional differences in productivity growth is the reallocation of labor towards sectors with higher productivity in Asia and towards sectors with lower productivity in Latin America. In other words, structural change was growth-enhancing in Asia, but growth-reducing in Latin America.

TABLE 8

DECOMPOSITION OF LABOR PRODUCTIVITY GROWTH, 1980s-2005

(Percentages)

\begin{tabular}{lccc}
\hline & $\begin{array}{c}\text { Labor Productivity } \\
\text { Growth (LPG) }\end{array}$ & Due to within sector LPG & Due to structural change \\
\cline { 3 - 4 } & 1.35 & 2.24 & -0.88 \\
Latin America and & 0.86 & 2.13 & -1.27 \\
Africa & 3.87 & 3.31 & 0.57 \\
Asia & 1.46 & 1.54 & -0.09 \\
High-income countries & & & \\
\hline
\end{tabular}

Source: McMillan and Rodrik (2011).

A more recent study suggests the situation is more complex and that the McMillan-Rodrik results are sensitive to the choice of time period. Using the same method as McMillan/Rodrik, Weller and Kaldewei (2013) calculate the 'within' and 'across' sector components of productivity growth in Latin American countries separately for the 1990s and for the 2000s. The results show a considerable improvement in the 2000s compared to the 1990s. During the 1990s, labor productivity growth was negative in many countries, often with a negative contribution of the intersectoral component and/or 
intra-sectoral component (see table 9). In the 2000s, in contrast, labor productivity growth rates were generally higher and positive, except for Nicaragua. And the inter-sectoral component was positive in all countries with the exception of the Dominican Republic and Nicaragua where it was slightly negative.

TABLE 9

DECOMPOSITION OF LABOR PRODUCTIVITY GROWTH INTO INTER- AND INTRA-SECTORAL COMPONENTS

\begin{tabular}{|c|c|c|c|c|c|c|c|c|}
\hline Country & Period & $\begin{array}{l}\text { Annual LP } \\
\text { growth }\end{array}$ & $\begin{array}{c}\text { Inter-sectoral } \\
\text { Component }\end{array}$ & $\begin{array}{c}\text { Intra-sectoral } \\
\text { Component }\end{array}$ & Period & $\begin{array}{l}\text { Annual } \\
\text { LP } \\
\text { growth }\end{array}$ & $\begin{array}{l}\text { Inter-sectoral } \\
\text { Component }\end{array}$ & $\begin{array}{c}\text { Intra-sectoral } \\
\text { Component }\end{array}$ \\
\hline \multicolumn{9}{|c|}{ Countries with annual labor productivity growth $\geq 3.5 \%$ in the ' $2000 \mathrm{~s}$ ' } \\
\hline Argentina* & $2002-2012$ & 3.9 & 0.2 & 3.7 & $1990-2002$ & 1.0 & 0.8 & 0.2 \\
\hline Ecuador & $2002-2012$ & 3.5 & 0.8 & 2.6 & $1990-2001$ & -0.7 & -0.1 & -0.6 \\
\hline Panama & $2002-2012$ & 4.8 & 0.3 & 4.5 & $1991-2002$ & 0.2 & 0.9 & -0.8 \\
\hline Peru & $2002-2011$ & 4.0 & 1.7 & 2.3 & 1994-2002 & -1.7 & -0.4 & -1.2 \\
\hline Uruguay & $2002-2011$ & 4.2 & 0.7 & 3.4 & $1990-2002^{a}$ & 1.8 & 0.9 & 0.9 \\
\hline \multicolumn{9}{|c|}{ Countries with annual labor productivity growth between $1 \%$ and $2.5 \%$ in the ' $2000 \mathrm{~s}$ ' } \\
\hline Brazil & $2002-2011$ & 1.9 & 0.7 & 1.2 & $1990-2002$ & -0.4 & 0.0 & -0.4 \\
\hline Chile & $2002-2012$ & 1.4 & 0.5 & 0.9 & $1990-2002$ & 3.4 & -0.2 & 3.6 \\
\hline Colombia & $2002-2012$ & 1.7 & 0.8 & 0.9 & $1991-2000$ & 1.0 & -0.3 & 1.3 \\
\hline Costa Rica & 2002-2012 & 2.3 & 0.1 & 2.2 & $1990-2002$ & 0.7 & 0.3 & 0.4 \\
\hline $\begin{array}{l}\text { Dominican } \\
\text { Republic }\end{array}$ & $2002-2012$ & 1.8 & -0.1 & 1.9 & 1991-2002 & 2.9 & 0.1 & 2.8 \\
\hline Guatemala & $2002-2011$ & 1.8 & 2.0 & 0.2 & Not avail. & & & \\
\hline Honduras & $2002-2012$ & 1.7 & 0.2 & 1.6 & $1990-2002$ & -0.4 & 0.5 & -0.9 \\
\hline $\begin{array}{l}\text { Venezuela } \\
\text { (Bolivarian } \\
\text { Republic } \\
\text { of) }\end{array}$ & $2002-2011$ & 1.5 & 1.7 & -0.2 & $1990-2002$ & -2.9 & 0.1 & 2.8 \\
\hline $\begin{array}{l}\text { Bolivia } \\
\text { (Plurinational } \\
\text { State of) }\end{array}$ & $2002-2009$ & 0.2 & 1.4 & -1.2 & $1996-2002$ & 1.5 & 0.1 & 1.4 \\
\hline $\begin{array}{l}\text { El } \\
\text { Salvador }\end{array}$ & 2002-2012 & 0.3 & 0.1 & 0.3 & $1992-2002$ & 1.4 & 1.3 & 0.1 \\
\hline \multicolumn{9}{|c|}{ Countries with annual labor productivity growth $<1 \%$ in the '2000s' } \\
\hline Mexico & $2002-2012$ & 0.8 & 1.1 & -0.3 & $1991-2002$ & -0.3 & 0.9 & -0.5 \\
\hline Nicaragua & $2002-2010$ & -0.7 & -0.1 & -0.6 & $1990-2003$ & -1.0 & 0.5 & -1.5 \\
\hline Paraguay & 2002-2011 & 0.5 & 0.2 & 0.3 & $1997-2002$ & -2.6 & -0.6 & -2.0 \\
\hline
\end{tabular}

Source: Data for the '1990s' from Weller and Kaldewei $(2013,49)$; data for the '2000s' from CEPAL. The data for the '1990s' are based on constant 1995 \$; the data for the '2000s' on constant 2005 \$.

a Urban.

Productivity growth during the last decade varied considerably among Latin American countries. Five countries did very well, with annual labor productivity growth of 3.5 percent or more (Argentina, Ecuador, Panama, Peru, Uruguay); in eight countries, the annual growth rate was between 1 and 2 percent; and in five countries, it was rather poor, below 1 percent.

Does the positive contribution of the inter-sectoral component to productivity growth bode well for the prospects of growth-enhancing structural change? The answer is negative if an expansion of employment in the manufacturing sector is the key. During the 2000s, employment in agriculture declined in all Latin American countries, except in El Salvador, Nicaragua and Panama. But labor was not absorbed by manufacturing; it went into construction and services (see table 10). Paraguay and Peru are the exception as the only two countries where the employment share in manufacturing actually increased. 
What are the consequences of this premature de-industrialization? Historically, growth-inducing structural change has meant a shift in production from the primary sector to higher value added activities in manufacturing, as the latter offers greater returns to scale, spillovers from learning and higher productivity potential. But in the current global context we have to answer three fundamental questions: (1) Is an expansion of the employment share in manufacturing still an option except for low-income economies with very low wages? (2) Can some of the internationally traded services and activities higher up the value chain in the primary sector (natural resources and agriculture) provide the scope for linkages, knowledge transfer and increasing returns similar to what manufacturing has offered in the past? And (3), do we need to separate the creation of decent employment from the dynamic creation of higher value added? It is beyond the scope of this study to answer these questions. Below I offer a few observations.

Services comprise a very heterogeneous set of activities. At the level of aggregation considered in the McMillan-Rodrik (2011) and Weller-Kaldewei (2013) studies there are four subsectors in services: (1) wholesale and retail trade, hotels and restaurants, (2) public utilities, transport, storage and communication, (3) finance, insurance and real estate, and (4) community, social and personal services. The data in Table 10 confirm what we would expect: public utilities and finance ( 2 and 3 ) tend to have higher productivity levels than manufacturing, and commerce and social services (1 and 4) generally have productivity levels that are lower than in manufacturing. But does an expansion in the employment share in (2) and (3) generate the same broad spillover effects as an employment expansion in manufacturing? The experience of the past suggests a negative answer to this question, as the incorporation and generation of new technologies was concentrated in the manufacturing sector. But the pervasiveness of ICT today along with the growing importance of bio-technology have blurred the lines between manufacturing and traded services. Whether this opens a new space for growth-enhancing structural change is an important area for future research.

What is clear at this juncture is that Washington Consensus policies led to increased productivity growth in Latin America's manufacturing sector without generating more employment (Paus et al. 2003). Jankowska et al. $(2012,13)$ capture the situation most aptly when they summarize:

The key aspect of successful structural transformation is the capacity of the modern sector to absorb a relevant share of workers from the traditional sector. ...Latin America is characterized by a manufacturing sector unable to compensate for the decreasing labour share in agriculture...Asian NICs are characterized by a process of structural transformation that is conducive to per capita income gains, as the modern sector simultaneously satisfies two important conditions: productivity is higher than in the traditional sector, and it is sufficiently labour-intensive so as to transmit these productivity gains to a sizeable share of the wage sector.

Markets work well at forcing producers to become efficient. But in the absence of technical, financial, or informational support to become competitive in existing activities, many smaller and midsized firms cannot enter or survive in international markets, especially when they have to compete with internationally established companies that benefit from economies of scale and better technological and marketing capabilities.

Even though the productivity differences across sectors have been declining in the course of the 2000 s, they are still larger than they were in the late 1990s. The coefficient of variation in productivity levels across productive sectors went from .94 in 1990 to 1.24 in 1998 to 1.05 in 2005 (ECLAC 2010, 91). Productivity differences within sectors are also large, indicating a high degree of structural heterogeneity. The productivity of micro enterprises in Chile, for example, is only 3 percent of that of a large company, while the equivalent ratio in France is 71 percent (ECLAC 2010, 95).

One of manifestations of insufficient employment absorption in the modern sector is the large size of the informal sector in Latin America. In 2012, informal employment accounted for 47.7 percent of all non-agricultural employment in Latin America. The share ranged from a low of 33.6 percent in Costa Rica and 38.4 percent in Brazil to a high of 68.8 percent in Peru and 70.7 percent in Honduras (ILO 2013). The ILO (2013) warns of the risk of an employment trap in the region. 


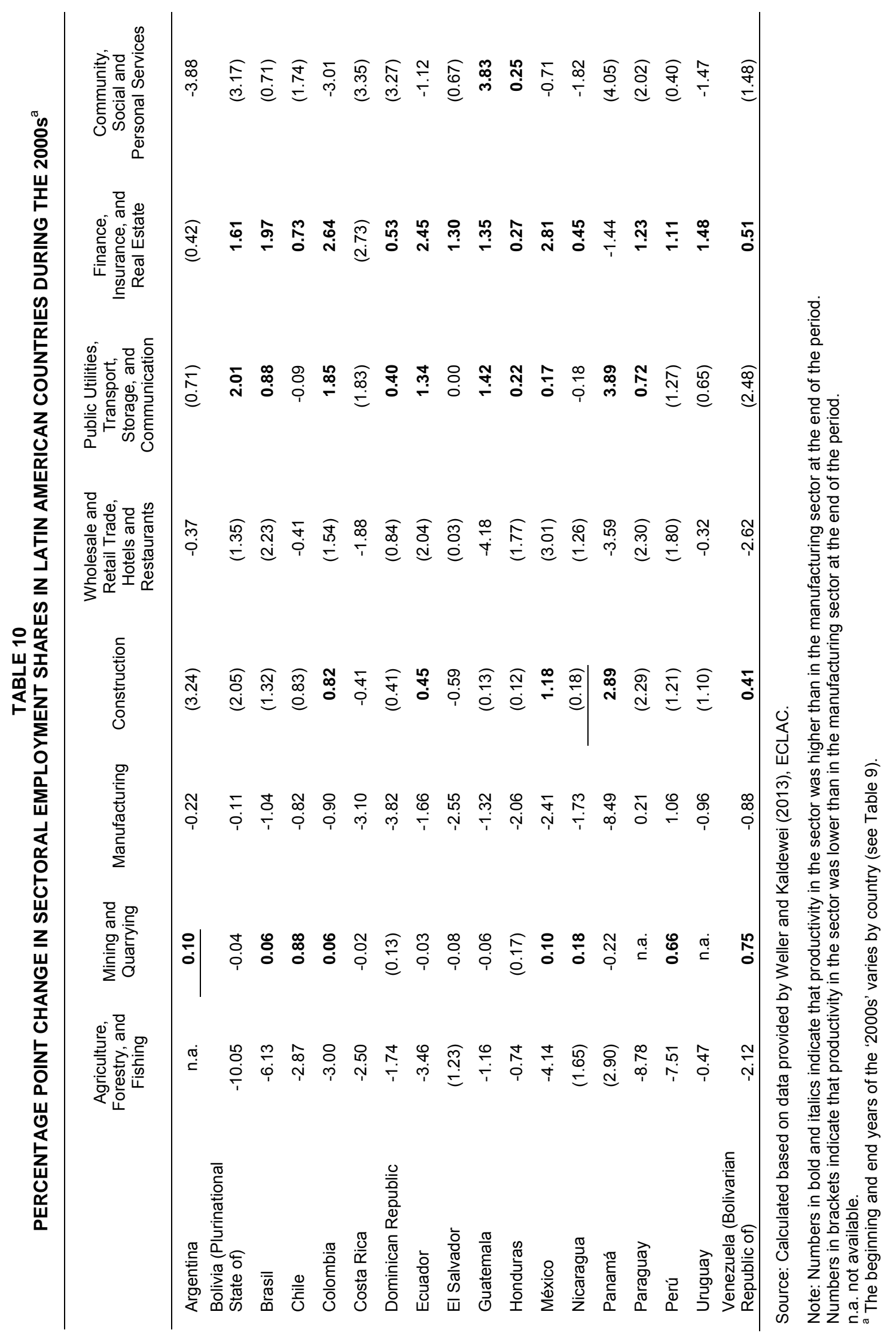




\section{The structure of exports}

There are clear differences in the patterns of structural change between South American economies on the one hand and Central American economies, the Dominican Republic and Mexico on the other. In South American countries, the share of manufacturing value added in GDP generally continued to decline during the 2000s, from 16.6 percent in 2000 to 13.7 percent in 2010 (see table 11). This trend can be found in all countries, even though Argentina started with a higher share.

A decomposition of exports complements this picture, as countries were deepening their (re)specialization in natural resources during the 2000s (see figure 4). In 2011, primary products accounted for more than 45 percent of export value in all countries, with the exception of Brazil where they made up only a third of exports. High-tech exports do not figure prominently among any of the South American countries; and Brazil and Argentina are the only countries where medium-tech exports make up between 20 to 25 percent of exports. The high reliance on primary products makes economic growth in South American countries very susceptible to fluctuations in commodity prices. The resulting volatility in growth may make it more difficult, yet also more urgent, to implement a long-term strategic focus on capability-accumulation for higher value added production.

The contrast with China's export profile could not be more pronounced. In 2011, one third of China's exports were high-tech goods, a quarter were medium-tech goods, and 30 percent were lowtech. China's structural change, in production and exports, has been moving towards higher-value added production. The manufacturing sector has accounted for more than 30 percent of economic output for the last two decades. In the other Asian middle-income countries, the manufactured share in value added is also much higher than in Latin America. The only exception is India, where manufacturing accounts for only 15 percent of GDP. In Vietnam, the manufacturing share is 'only' around 20 percent, but it has been growing, not falling, for the last 20 years.

\section{FIGURE 4 \\ DECOMPOSITION OF EXPORTS BY TECHNOLOGY INTENSITY: SOUTH AMERICAN COUNTRIES AND CHINA}

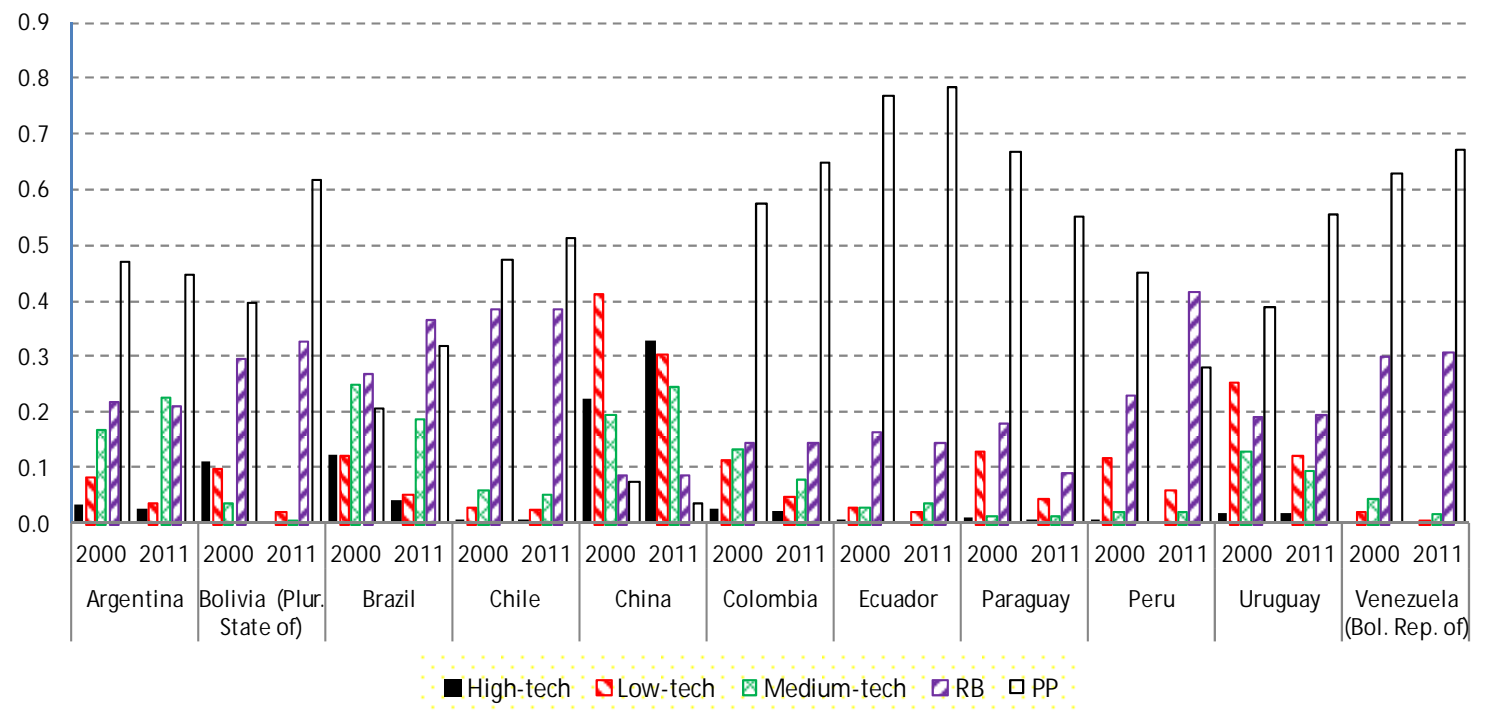

Source: Author's calculations based on UN-Comtrade. The technology classification is based on Lall (2000).

In Central America, the Dominican Republic and Mexico, the story is different from South America, as economies have different endowments and are more integrated into global production chains, predominantly from US transnational corporations (TNCs). The share of manufacturing value added in GDP is higher than in South America and has held relatively steady (see figure 4b). 
Non-primary products account for a significant share of exports (see figure 5). Maquila-based production plays an important role as countries have preferential access to the US market through a number of trade agreements: the Caribbean Basin Initiative, the CAFTA-DR Free Trade Agreement with the US, and the NAFTA Free Trade Agreement which includes Mexico, the US and Canada. Apparel classified as low-tech - is dominant in El Salvador, Guatemala, Honduras, and Nicaragua. In Mexico, in contrast, maquila-based exports are more diversified. The automotive sector plays a prominent role, as reflected in the large share of medium-tech products. Costa Rica is the only country where high-tech exports dominate. That is primarily due to the fact that the country was able to attract TNCs in the assembly of electronic and medical devices, most importantly a test-and-assembly plant for micro chips by Intel.

TABLE 11

MANUFACTURING VALUE ADDED AS A SHARE OF GDP (Unweighted averages)

\begin{tabular}{lccc}
\hline & 1991 & 2000 & 2010 \\
\hline South America $^{\mathrm{a}}$ & 20.8 & 16.6 & 13.7 \\
Central America $^{\mathrm{b}}$ and Dominican Republic & n.a. & 19.8 & 17.6 \\
Mexico & 20.6 & 20.3 & 18.1 \\
China & 32.5 & 32.1 & 29.5 \\
India & 15.2 & 15.4 & 14.9 \\
Malaysia, Indonesia, Thailand & 25.1 & 30.7 & 28.3 \\
Vietnam & 13.1 & 18.6 & 19.7 \\
\hline
\end{tabular}

Source: Based on World Development Indicators, on-line, accessed October 28, 2013.

${ }^{a}$ South America: Argentina, Boliva (Plurinational State of), Brazil, Chile, Colombia, Ecuador, Paraguay, Peru, Uruguay, Venezuela (Bolivarian Republic of).

${ }^{\mathrm{b}}$ Central America: Costa Rica, El Salvador, Guatemala, Honduras, Nicaragua, Panama.

FIGURE 5

DECOMPOSITION OF EXPORTS BY TECHNOLOGY INTENSITY: CENTRAL AMERICAN COUNTRIES, MEXICO, AND THE DOMINICAN REPUBLIC

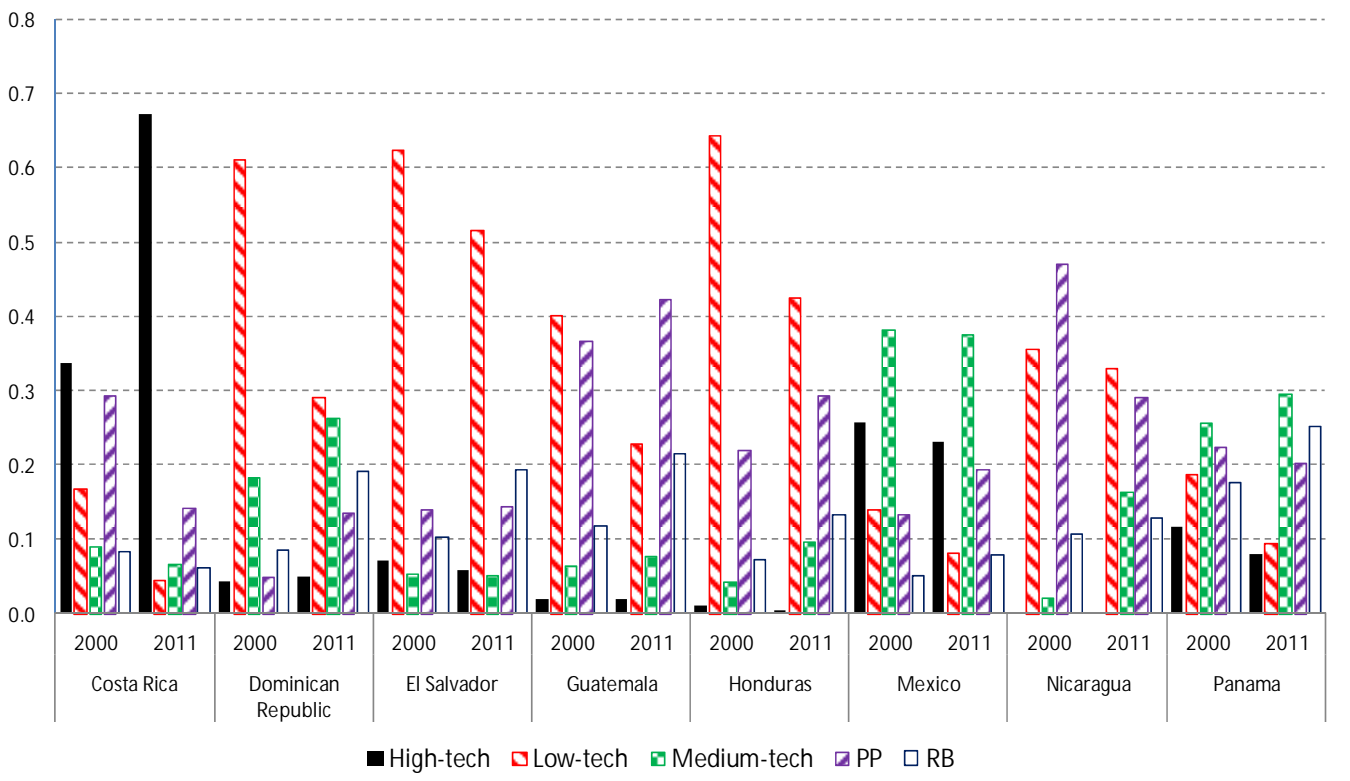

Source: Author's calculation based on UN-Comtrade. The technology classification is based on Lall (2000).

Note: World imports are used a proxy for countries' exports. 
Primary products also play an important role in some Central American countries. Their growth is often the result of the development of non-traditional agricultural fruits and vegetables, in addition to the old staples of coffee and bananas. But in spite of the differences in economic structure, most countries in South and Central America share a common challenge of inadequate productive capabilities, especially in the area of the capabilities for the expansion of knowledge-intensive activities.

These inadequacies are reflected in countries' inability to take advantage of the huge potential offered by the large and growing markets in China (and India). Exporters of natural resources have benefitted greatly from the commodity price boom, driven to a large extent by demand from China. But apart from natural resource exporters, most producers in Latin America have not been able to compete in Chinese markets. Latin American countries have seen the trade deficit with China balloon over the last decade. The only exceptions are Brazil, Chile, and Peru (due to their large exports of iron ore, copper, and soy beans) and Costa Rica (due to Intel's exports). In addition, Latin American producers have lost market share to China in third markets (Gallagher and Porzecansky 2010), and increasingly in regional and home markets as well (Jenkins, forthcoming). Indeed, there are indications that, for some countries, exports to China actually led to a downgrading, where the value added in exports declined rather than increased. Uruguay, for example, saw a decrease in the export of wool tops to China and an increase in unprocessed wool (Paus 2009).

Against the backdrop of generally poor productivity performance and growth-reducing or growthuncertain structural change, it is important to highlight that there are significant areas of upgrading excellence in Latin America. Those range from Embraer in Brazil to Cafe Britt in Costa Rica, from wine and salmon in Chile and cut flowers in Colombia to veterinary vaccines in Uruguay (Sabel et al. 2012). The growth of the "Translatinas", Latin American transnational corporations, are evidence of expanding international competitiveness in specific areas. Translatinas tend to be concentrated in the intermediate goods section (e.g. iron ore and cement), construction, and retail. But their international competitiveness contrasts sharply with the situation of most producers in Latin America. The overwhelming majority of enterprises are micro or small and produces for the local market.

\section{B. Social and firm level capabilities}

A change in the structure of production towards higher value added activities depends upon the requisite advancement of social and firm level capabilities. While there have been positive developments in these areas in Latin America, there are also serious inadequacies in education, infrastructure, innovation, and access to credit.

\section{Composite indices for Latin America and Asia}

An assessment of a country's productive capabilities and competitiveness and of their main determinants requires that we look at many different indicators and their interactions. It is thus not surprising that, over the last 10 years, we have seen the emergence of a number of summary measures that attempt to capture in one single index a country's ability to innovate and produce more sophisticated output and its ability to compete globally. The most prominent composite indicators are the Global Innovation Index (Cornell University, INSEAD, WIPO), the Logistics Performance Index (World Bank), the Competitive Industrial Performance Index (UNIDO), the Global Competitiveness Index (World Economic Forum), the World Competitiveness Scoreboard (IMD, Lausanne), and - most recently - the Human Capital Index, which the World Economic Forum published in the fall of 2013. These indices are based on many different sub-indicators; most include quantitative and qualitative information; and they differ in country coverage (see Box 1).

Table 12 shows how Latin American countries and second generation Asian NICs rank on the different indices. Among Latin American countries Chile tends to rank high across the various indices, while other countries like Bolivia (Plurinational State of) and Honduras tend to rank consistently low. But for some countries, the rankings can differ considerably depending on the index. Mexico, for example, ranks 22nd on the Industrial Competitiveness Index (out of 135 countries), but it ranks 72nd on the Knowledge Economy Index (out of 145 countries). 
Global Innovation Index 2013 (Cornell University, INSEAD, WIPO 2013)

Based on two sub-indices: the Innovation Input Sub Index and the Innovation Output Sub Index. The Innovation Input Sub-index, in turn, comprises five pillars: institutions, human capital and research, infrastructure, market sophistication, and business sophistication. The Innovation Output Index includes knowledge and technology outputs as well as creative outputs. There are 84 indicators in total. The index covers 142 countries.

\section{Competitive Industrial Performance Index 2010 (UNIDO)}

Based on three dimensions (eight indicators): (1) capacity to produce and export manufactures (MVA p.c., MX p.c), (2) technological deepening and upgrading (industrialization intensity - the average of high and medium manufacturing VA in total manufacturing and manufacturing VA in GDP - and manufactured exports quality - share of manufactured exports in total exports), (3) World impact (country's share in world manufactured value added, country's MX in world MX). The Index covers 135 countries.

Logistics Performance Index 2012 (World Bank, Ipi.worldbank.org)

Based on 6 indicators: customs, infrastructure, international shipments, logistics competence, tracking and tracing, timeliness. The index covers 155 countries.

Global Competitiveness Index 2013 (World Economic Forum 2013)

Based on 3 subindices: basic requirements subindex (institutions, infrastructure, macroeconomic environment, health and primary education), efficiency enhancers subindex (higher education and training, goods market efficiency, labor market efficiency, financial market development, technological readiness, market size), innovation and sophistication factors subindex (business sophistication, innovation). The 2012 index covers 153 countries.

Human Capital Index 2013 (World Economic Forum)

It includes 51 variables, grouped under 4 pillars: education, health and wellness, workforce and employment, and enabling environment. It uses both quantitative and qualitative evidence. The index covers 122 countries.

World Competitiveness Scoreboard 2012 (International Institute for Management Development, Lausanne)

20 subfactors, 247 criteria related to economic performance, government efficiency, business efficiency, infrastructure. The scoreboard covers 59 countries.

Knowledge Economy Index 2012 (World Bank)

Based on four sub-indices: economic incentives and institutional regime, innovation and technological adoption, education and training, ICT infrastructure. It includes 148 structural and qualitative variables. The index covers 145 countries.

Source: Author's own elaboration.

Figures 6, 7, and 8 map the relationship between GDP p.c. and the Human Capital Index, the Logistics Performance Index and the Global Innovation Index, respectively. We find a negative relationship between each of the indices and GDP p.c. In other words, countries with a higher GDP p.c. tend to be better ranked on the index. But there is considerable variation around the trend. Among Latin American countries, it is harder to establish clear groupings. Paraguay, Bolivia (Plurinational State of), Venezuela (Bolivarian Republic of), and the Central American countries tend to score worse than predicted by the trend line. Costa Rica is the notable exception in Central America. Brazil, Chile, Peru, Uruguay, Colombia and Peru tend to hover around the trend line. The Asian countries, in contrast, tend to score better than predicted by the trend line. That is especially true for China and Malaysia. 
FIGURE 6

HUMAN CAPITAL INDEX AND GDP P.C.

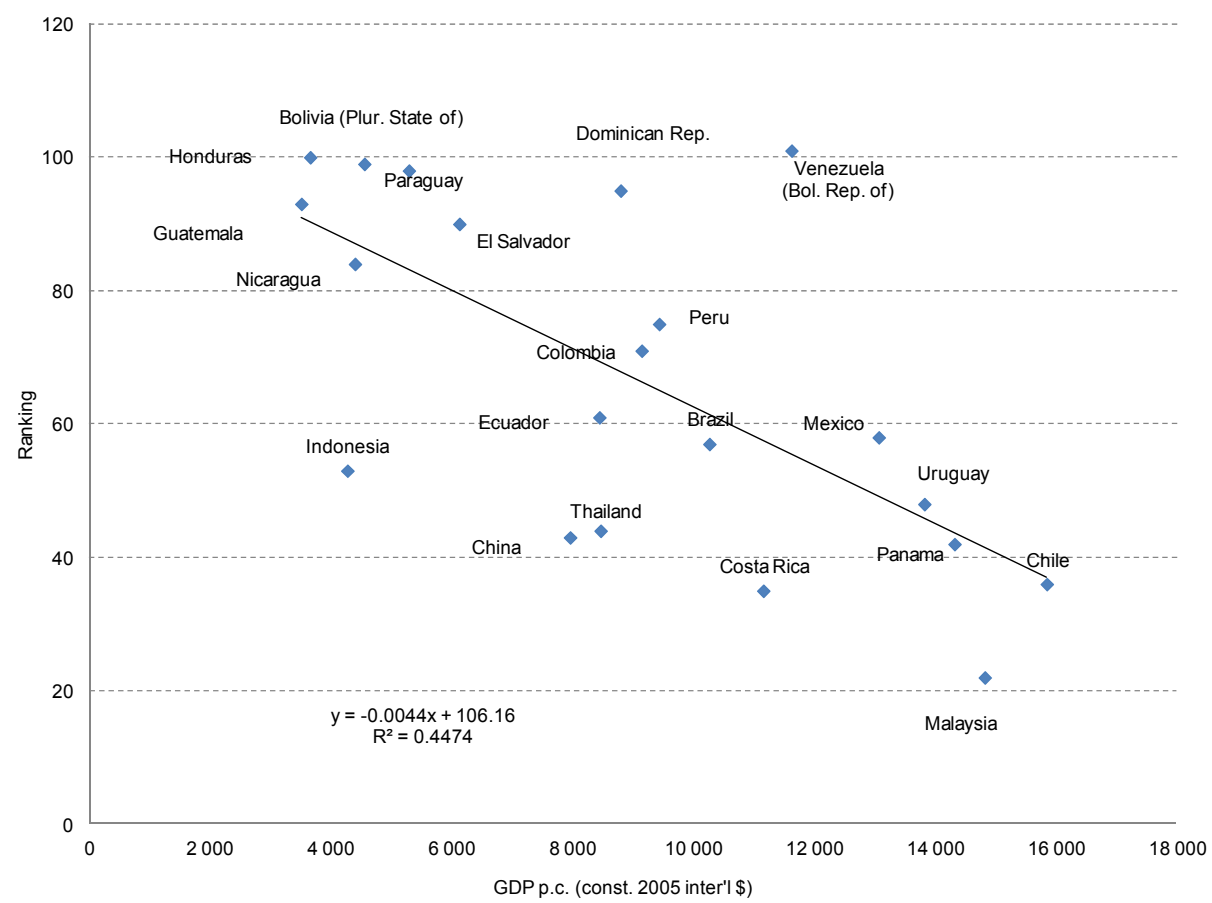

Source: World Development Indicators on-line and World Economic Forum (2013).

FIGURE 7

LOGISTICS PERFORMANCE INDEX AND GDP P.C.

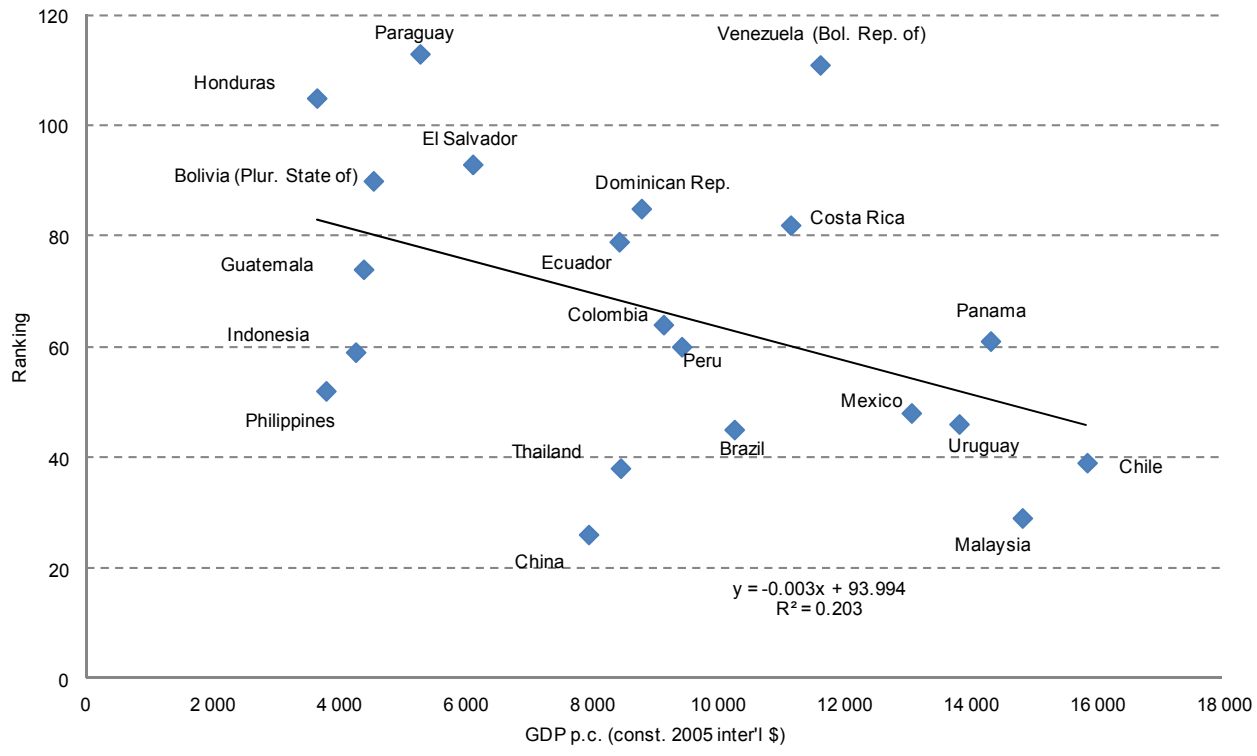

Source: World Development Indicators on-line and Ipi.worldbank.org. 


\section{GLOBAL INNOVATION INDEX AND GDP P.C.}

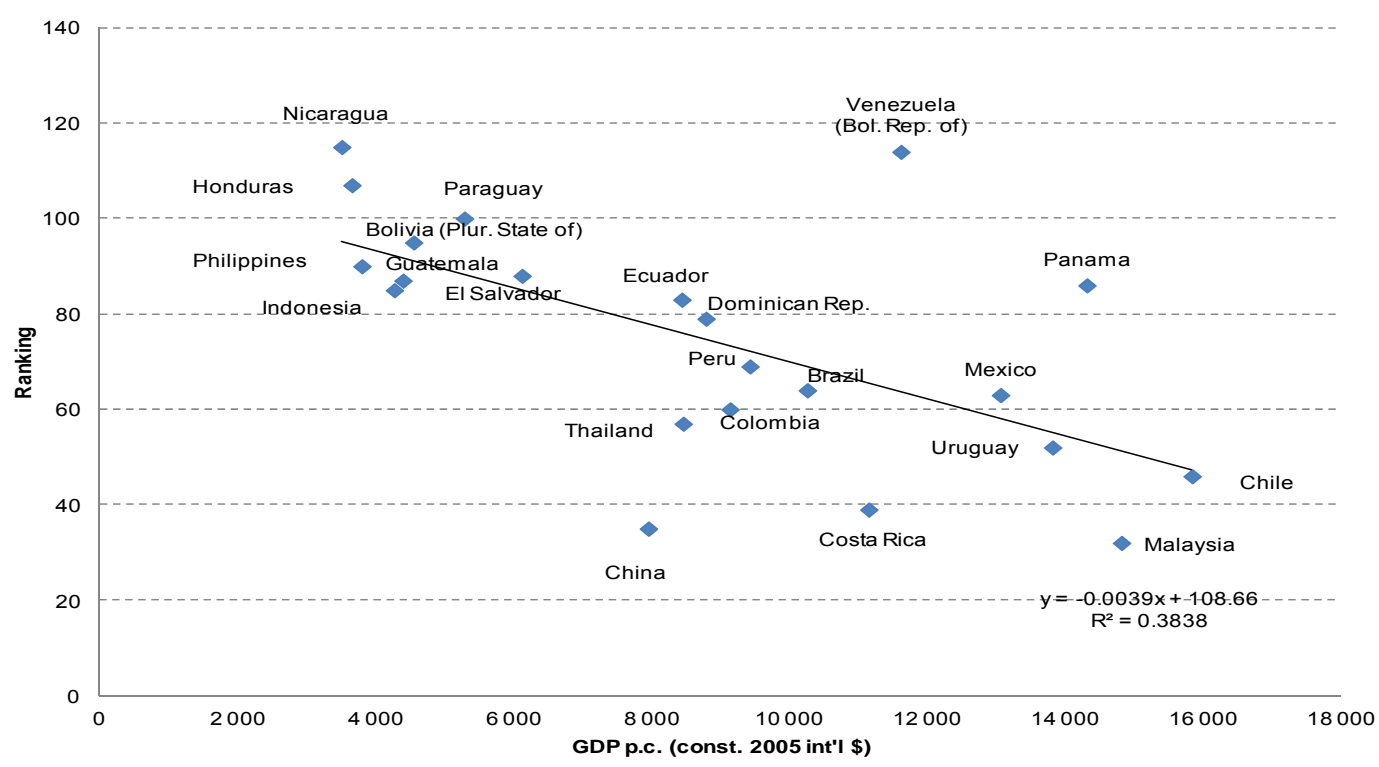

Source: World Development Indicators on-line and Cornell University et als (2013).

But composite indicators can tell us only so much, given that most of them mix qualitative and quantitative data, that they mix input and output data, and that the inclusion of variables and choice of weights inevitably contains an element of subjectivity. In addition, poor performance on one indicator may be compensated by good performance on another indicator. But that is misleading if some variables have to evolve jointly to generate the desired development impact.

The main inference we can glean from these comparisons is that the Asian countries, and not only China, outrank the Latin American countries consistently. Below we take a closer look at select discrete indicators of social and firm level capabilities to get a better sense of how Latin American countries fare in specific areas, and where policies might intervene.

\section{Education}

The education indicators for Latin America suggest a very mixed picture. Between 1990 and 2010, the average number of years of schooling of the economically active population increased from 8.6 to 9.8 years in urban areas and from 4.8 to 6.3 years in rural areas (Weller and Kaldewei 2013, 28). Secondary enrolment rates in Latin America have increased considerably over the last two decades, putting the region above East Asian developing economies and the average for middle-income countries (see table 13). But in some countries, drop-out rates are high (e.g., Costa Rica), and access to decent education is highly unequal in many countries. 


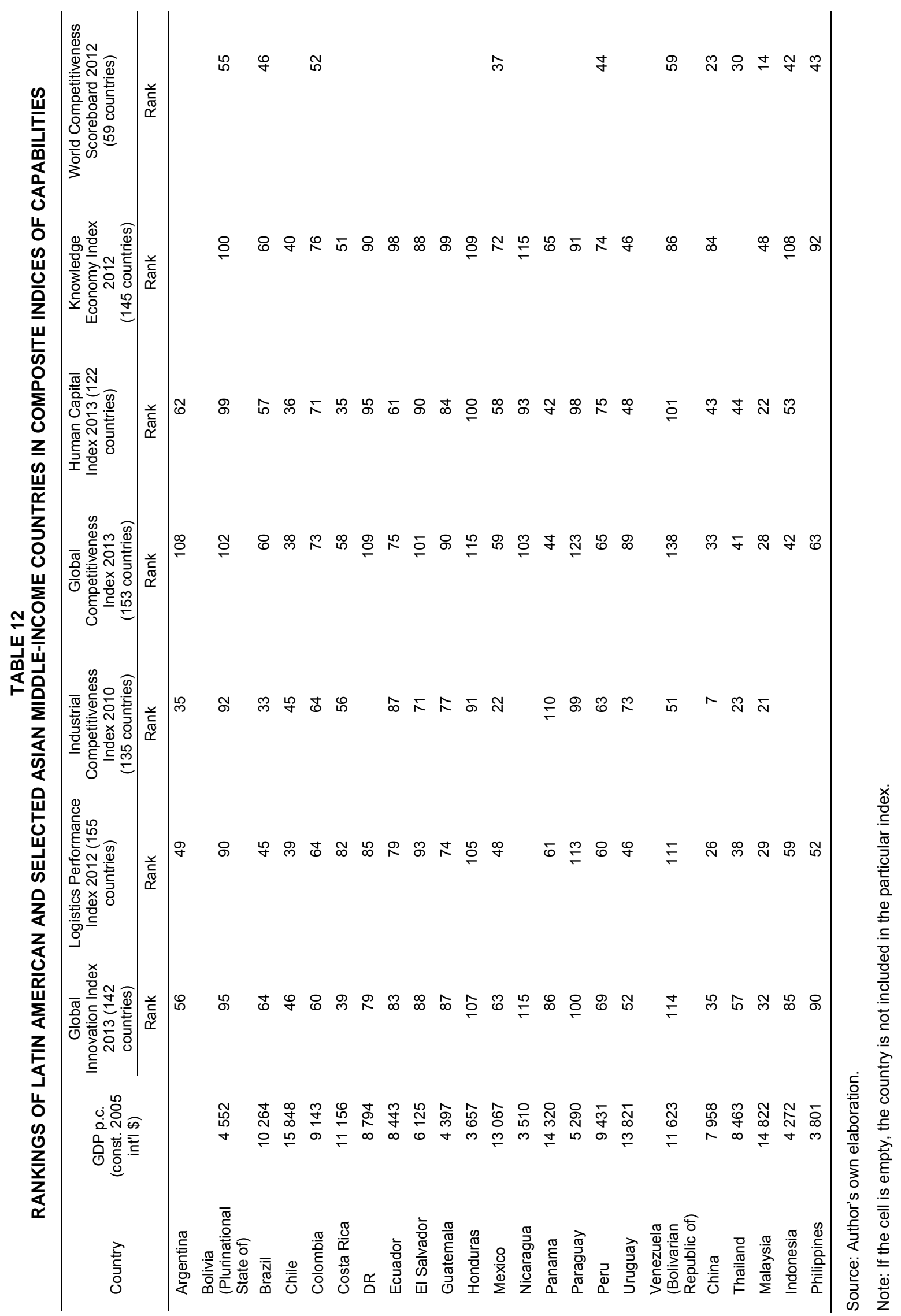


TABLE 13

ENROLMENT RATES

\begin{tabular}{|c|c|c|c|c|c|}
\hline & \multicolumn{5}{|c|}{ Secondary Enrolment Rates (gross) } \\
\hline & 1970 & 1980 & 1990 & 2000 & 2010 \\
\hline East Asia and Pacific (developing only) & 27 & 43 & 39 & 60 & 77 \\
\hline Latin America and Caribbean (all income levels) & 28 & 50 & 61 & 83 & 90 \\
\hline Middle income & 29 & 41 & 44 & 57 & 71 \\
\hline \multirow[t]{3}{*}{ OECD members } & 72 & 81 & 86 & 95 & 99 \\
\hline & \multicolumn{5}{|c|}{ Tertiary Enrolment Rates (gross) } \\
\hline & 1970 & 1980 & 1990 & 2000 & 2010 \\
\hline East Asia and Pacific (developing only) & 1 & 3 & 5 & 12 & 26 \\
\hline Latin America and Caribbean (all income levels) & 7 & 13 & 17 & 23 & 41 \\
\hline Middle income & 4 & 6 & 8 & 13 & 25 \\
\hline OECD members & 24 & 31 & 38 & 51 & 68 \\
\hline
\end{tabular}

Source: World Development Indicators, on-line, October 28, 2013.

TABLE 14

PISA SCORES, 2012

\begin{tabular}{lccccc}
\hline \multicolumn{5}{c}{} & \multicolumn{2}{c}{ Math Literacy } & Average & $\begin{array}{c}\text { Share of low } \\
\text { performers } \\
\text { Score }\end{array}$ & $\begin{array}{c}\text { Share of high } \\
\text { performers } \\
\text { (below level 2) }\end{array}$ & $\begin{array}{c}\text { Average Science } \\
\text { Literary Score }\end{array}$ & $\begin{array}{c}\text { Average Reading } \\
\text { Score }\end{array}$ \\
\cline { 2 - 4 } Shanghai & 613 & 3.8 & 55.4 & 580 & 570 \\
Singapore & 573 & 8.6 & 40.0 & 551 & 542 \\
Hong Kong & 561 & 8.5 & 33.7 & 555 & 545 \\
Taiwan & 560 & 12.8 & 37.2 & 523 & 523 \\
South Korea & 554 & 9.1 & 30.9 & 538 & 536 \\
Vietnam & 511 & 14.2 & 13.3 & 506 & 508 \\
Malaysia & 421 & 51.8 & 1.3 & 420 & 398 \\
Indonesia & 377 & 75.7 & 0.3 & 396 & 382 \\
Chile & & & & & 445 \\
Mexico & 423 & 51.5 & 1.6 & 441 & 424 \\
Uruguay & 413 & 54.7 & 0.6 & 415 & 411 \\
Costa Rica & 409 & 55.8 & 1.4 & 416 & 441 \\
Brazil & 407 & 59.9 & 0.6 & 429 & 405 \\
Argentina & 391 & 67.1 & 0.8 & 410 & 396 \\
Colombia & 388 & 66.5 & 0.3 & 406 & 403 \\
Peru & 376 & 73.8 & 0.3 & 399 & 384 \\
\hline
\end{tabular}

Source: OECD $(2013,5)$. 
TABLE 15

DOCTORAL DEGREES, 2008 OR MOST RECENT YEAR

\begin{tabular}{lrc}
\hline Country & All fields & Share in science and engineering \\
\hline Brazil & 10705 & 51.1 \\
Mexico & 3498 & 47.5 \\
Argentina & 696 & 62.8 \\
Chile & 307 & 73.9 \\
Colombia & 102 & 68.6 \\
Panama & 11 & 36.4 \\
Uruguay & 28 & 85.7 \\
China & 43759 & 65.0 \\
South Korea & 9367 & 39.7 \\
Taiwan & 3140 & 63.9 \\
India & 18730 & 42.6 \\
United States & 61716 & 54.1 \\
Germany & 25604 & 44.2 \\
Japan & 17291 & 46.4 \\
\hline
\end{tabular}

Source: National Science Board, 2012, from Appendix Table 2-35.

The PISA scores — an indicator of educational outcomes - are only available for a limited number of Latin American countries table 14). The scores indicate that Latin American countries are far below the successful first generation NICs in East Asia. An aggregate score for China is not available; it would undoubtedly be lower than that of Shanghai. Nonetheless, it is remarkable that Shanghai tops the list for all the countries, not just the ones listed in table 14.

The PISA scores indicate that Vietnam is clearly a country to reckon with in international competition in the future. In 2012, Vietnam's GDP p.c. was \$ 986 (in constant 2005 US \$), less than 30 percent of the GDP p.c. in Nicaragua, the poorest Latin American country included in this paper.Yet Vietnam's PISA scores are higher than Chile's, which has the highest GDP p.c. $(\$ 15,848)$ among the Latin American countries included here.

The scores for Latin American countries are not unlike those for Indonesia and Thailand though. The distribution of performance within Latin America and Indonesia and Thailand is striking. More than half of the test takers performed below level 2 in math; in Colombia, Peru, and Indonesia, the proportion of low performers even reached three quarters. The share of students on the other end of the spectrum is very small. High performers (levels 5 or 6 ) accounted for less than 2 percent, and in most countries for less than 1 percent. This highly skewed distribution of educational outcomes is linked to the highly unequal access to decent education in many countries (Foxley 2012). It is not a strong basis on which to move towards a greater knowledge economy.

On the other hand, tertiary enrolment rates are promising, as is the percentage of doctoral degrees in science and engineering (table 15). The overall number of doctorates granted in the sciences is still rather small though, except for Brazil and Mexico.

\section{Infrastructure}

Latin America lags significantly behind East Asian and other middle-income countries in infrastructure, in quantity as well as quality. One of the main reasons is the decline in public investment. As governments sought to curtail fiscal deficits in the aftermath of the foreign debt crisis of the 1980s, a lot of the adjustment burden fell on capital spending. The weighted average of public investment in infrastructure for six major Latin American countries declined from 3 percent of GDP in the first half of the 1980s to less than 1 percent in the first half of the 2000s (table 16). Private investment made up some of the decline in public investment. Yet it fell considerably short of compensating for it, with the 
exception of Chile. As a result, total investment in infrastructure fell from 3.6 to 1.9 percent of GDP between the early 1980 s and 2000 s.

In a recent comparison of infrastructure spending in countries and regions around the world, Latin America ranked at the very bottom of the list (table 17). During 1992-2011, spending on infrastructure accounted for 1.8 percent of GDP in Latin America. In China, in contrast, it accounted for 8.5 percent! The government is the main spender on infrastructure in China, providing 96 percent of the funding (Chen et al. 2013, 11).

TABLE 16

PUBLIC AND PRIVATE INVESTMENT IN INFRASTRUCTURE IN LATIN AMERICA AS A SHARE OF GDP, 1981-2006

\begin{tabular}{lllll}
\hline & & Total & Public & Private \\
\hline Argentina & $1981-86$ & 2.76 & 2.75 & 0.00 \\
& $2001-06$ & 1.67 & 0.68 & 0.98 \\
Brazil & $1981-86$ & 5.15 & 3.60 & 1.54 \\
& $2001-06$ & 2.11 & 1.15 & 0.97 \\
Chile & $1981-86$ & 3.44 & 3.44 & 0.00 \\
& $2001-06$ & 5.21 & 1.68 & 3.53 \\
Colombia & $1981-86$ & 3.13 & 3.13 & 0.00 \\
& $2001-06$ & 2.77 & 1.68 & 1.08 \\
Mexico & $1981-86$ & 2.44 & 2.44 & 0.00 \\
& $2001-06$ & 1.23 & 0.53 & 0.69 \\
Peru & $1981-86$ & 2.11 & 2.07 & 0.04 \\
& $2001-06$ & 1.49 & 0.54 & 0.96 \\
Weighted average & $1981-86$ & 3.62 & 3.00 & 0.62 \\
(by GDP) & $2001-06$ & 1.89 & 0.89 & 0.99 \\
\hline
\end{tabular}

Source: Calderón and Servén, 2010, from table 4, p. 51.

TABLE 17 SPENDING ON INFRASTRUCTURE AS A SHARE OF GDP, 1992-2011

\begin{tabular}{lc}
\hline Country/Region & $\begin{array}{c}\text { Amount Spent on Infrastructure as a Share } \\
\text { of GDP (weighted) }\end{array}$ \\
\hline China & 8.5 \\
Other industrialized countries $^{\mathrm{a}}$ & 5.0 \\
Japan & 4.7 \\
India & 3.9 \\
Middle East and Africa & 3.6 \\
Eastern Europe/Eurasia & 3.3 \\
European Union & 2.6 \\
United States & 2.6 \\
Latin America & 1.8 \\
\hline
\end{tabular}

Source: Chen et al. $(2013,9)$.

${ }^{a}$ Twelve countries incl. Australia, Canada, South Korea, Switzerland, UAE. 
TABLE 18

PERCENTAGE OF ROADS PAVED

\begin{tabular}{lcc}
\hline & 2003 & 2010 \\
\hline Developing East Asia and Pacific & $14.4^{\mathrm{a}}$ & 50.6 \\
China & $40.3^{\mathrm{a}}$ & $53.5^{\mathrm{b}}$ \\
Indonesia & $58.3^{\mathrm{c}}$ & $59.1^{\mathrm{b}}$ \\
Malaysia & $80.8^{\mathrm{a}}$ & 80.4 \\
Thailand & $98.5^{\mathrm{c}}$ & $\mathrm{n} . \mathrm{a}$. \\
Latin America and Caribbean & 33.3 & 23.3 \\
Brazil & $5.5^{\mathrm{c}}$ & 13.5 \\
Chile & $18.4^{\mathrm{c}}$ & 23.3 \\
Mexico & 35.8 & 36.4 \\
Middle-income countries & 39 & 55 \\
Sub-Saharan Africa & 18.1 & 16.3 \\
\hline
\end{tabular}

Source: World Development Indicators, on-line, accessed October 2013.

2005.

${ }^{\mathrm{b}} 2008$.

${ }^{\mathrm{c}} 2000$.

TABLE 19

MOBILE PHONE AND INTERNET USERS (PER 100 PEOPLE), 2010

\begin{tabular}{lrc}
\hline & Mobile Cellular Users & Internet Users \\
\hline Developing East Asia and & 70.7 & 29.3 \\
Pacific & 64 & 34.3 \\
China & 88.1 & 10.9 \\
Indonesia & 119.2 & 56.3 \\
Malaysia & 103.8 & 22.4 \\
Thailand & 96.8 & 34.7 \\
Latin America and Caribbean & 101.1 & 40.6 \\
Brazil & 116 & 45 \\
Chile & 80.6 & 31.1 \\
Mexico & 73.7 & 22.8 \\
Middle-income countries &
\end{tabular}

Source: World Development Indicators, on-line, accessed October 28, 2013.

Perrotti and Sánchez $(2011,63)$ calculate that the infrastructure investment ratio would have to be 7.9 percent of GDP in Latin America to close the gap with East Asia This poses a huge challenge in the coming years.

Not all infrastructure components in Latin America have been affected equally by the decline in the spending share. At the aggregate level, total investment in telecommunications increased from 0.46 percent to 0.66 percent of GDP. The investment share remained unchanged for water and sanitation, at 0.23 percent. But it declined considerably in electric power, from 1.91 percent to 0.51 percent, and in roads and railways from 1.02 percent to 0.50 percent (Calderón and Servén 2010, 51).

During the 2000s, the percentage of roads paved actually declined in Latin America, and by 2010, it was less than half of that in middle-income countries and East Asian economies (table 18). The one good news on the infrastructure side is the pervasiveness of Internet and mobile phone usage. That is 
particularly important in an era where IT-based communications are becoming ever more critical for business (table19).

\section{Firm level capabilities, with a focus on innovation}

The development of local firm capabilities, as a collective ability for a critical mass of firms, involves different aspects, all of which are aimed at raising value added. Pietrobelli and Rabellotti (2006) define upgrading as "innovating to increase value added." Economists commonly distinguish between process innovation, where a firm introduces new technology or re-organizes the production process to produce an existing product more efficiently, and product innovation, where a firm brings a new product to market. From a capability perspective, it is useful to consider two additional types of upgrading (Humphrey and Schmitz 2000). One is functional upgrading, where firms move into design, marketing, and more complex activities, and the other is inter-sectoral upgrading where firms use the capabilities acquired in one sector to move to another sector. Lall (1992) lays out a complex typology for the development of organizational and technological capabilities within and among firms.

Here we will only look at two aspects of firm level capabilities, spending on research and development (R\&D) and patents. Under the Washington Consensus regime, these innovation capabilities generally did not advance much in Latin America,with the exception of Brazil, research and development (R\&D) expenditures account for a much lower share of GDP than would be expected at countries' income levels, especially in Central America (see figure 9). China, on the other hand, has an $\mathrm{R} \& \mathrm{D}$ ratio that is much higher than predicted. In 2010, China's R\&D ratio was 1.75 percent (World Bank 2012, 176), more than double that of any Latin American country, except for Brazil.

FIGURE 9

R\&D INTENSITY IN MIDDLE-INCOME COUNTRIES, 2007

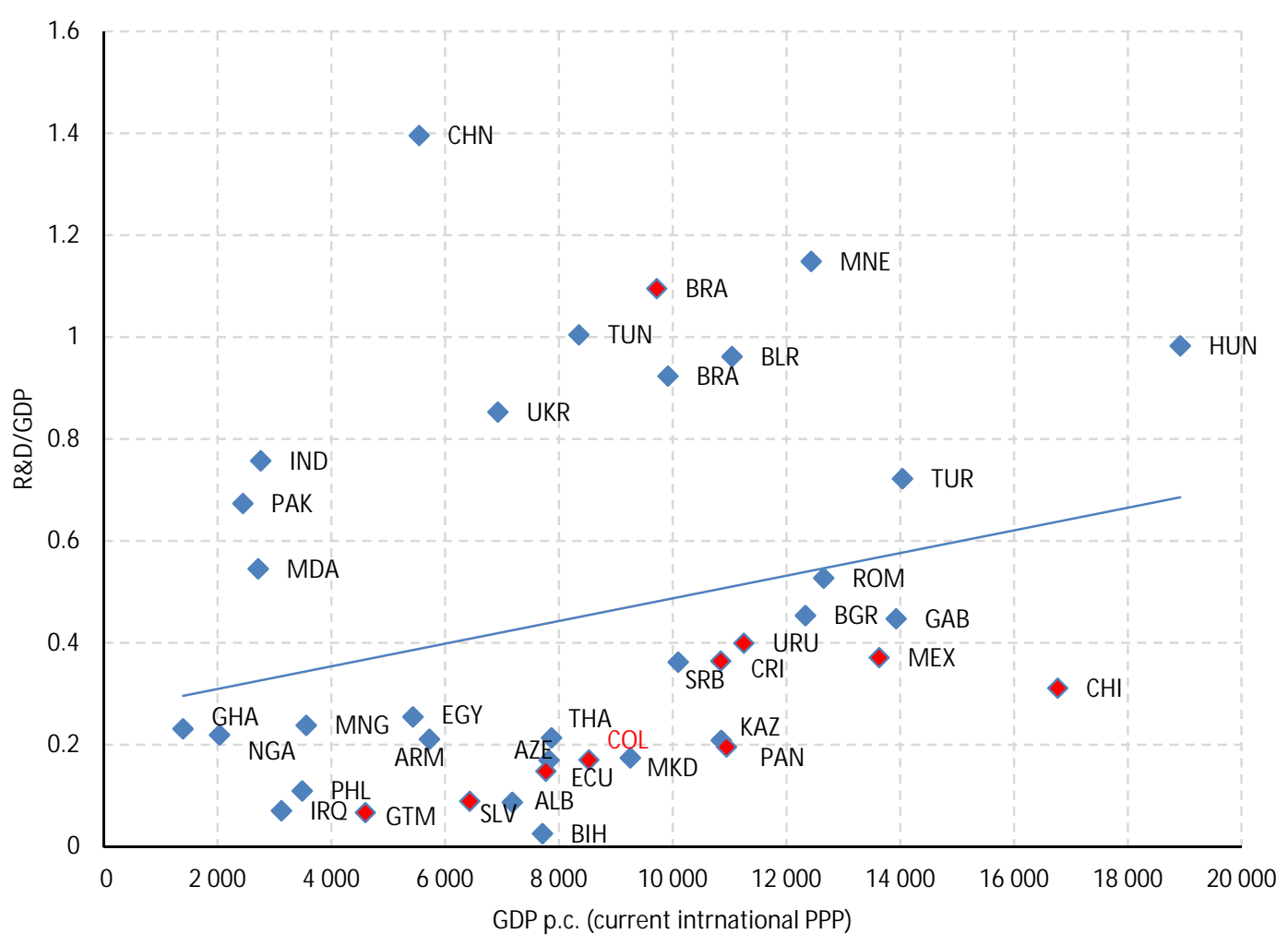

Source: World Development Indicators on-line.

Note: Note that Chile and Uruguay are high-income countries in the World Bank classification. 
Latin American countries are not the only middle-income countries lacking in the advancement of innovation. In a study of the second tier NICs in Asia (Indonesia, Malaysia, Philippines and Thailand), Yusuf and Nabeshima $(2009 \mathrm{~b}, 10)$ point out that both indigenous firms and TNC affiliates conduct very little innovation. They argue that "unlike the original East Asian Tiger economies, the Southeast Asian Tigers have yet to build the indigenous capacity to design, to innovate and to diversify into new and more profitable areas with good long-run prospects, and very few of their firms have created regional — much less global— brand names."

Not surprisingly, data on innovation outputs mirrors the picture for innovation inputs. The number of patents granted by the US patent office to Argentina, Brazil and Mexico increased between 1995 and 2010, but they were a only a fraction of the patents granted to China (see table 20).

Argentina, Brazil, and Mexico account for over 80 percent of patent applications in Latin America, for residents and non-residents alike. A key indicator of a country's success in catching up technologically is the share of patent applications by residents relative to non-residents (Lee 2013). In Latin America, the number of patent applications more than doubled between the early 1990s and the late 2000s. But the share of resident patent applications in the total declined, from 23 percent in 1985 to 12 percent in 2009 (table 21). In East Asian developing countries, in contrast, the share increased from 5 percent to 37 percent. And in China, it rose from 47 percent to 73 percent!

In most Latin American countries, government support for innovation has been weak. Governments following Washington Consensus policies put too much emphasis on short-term efficiencies and paid too little attention to the fact that learning takes time, that innovation needs to be supported with the right incentive structure, and that collaborations among the academy, the private sector and public research institutions require deliberate coordination.

TABLE 20

PATENT INFORMATION, USPTO PATENT GRANTS

\begin{tabular}{lccc}
\hline & $1995-1999$ & $2000-2004$ & $2005-09$ \\
\hline Argentina & 185 & 267 & 192 \\
Brazil & 361 & 552 & 509 \\
Mexico & 286 & 459 & 341 \\
& & & \\
China & 989 & 2700 & 6641 \\
South Korea & 11398 & 19051 & 32871 \\
Taiwan & 12422 & 26794 & 30576 \\
India & 339 & 1316 & 2838 \\
\hline
\end{tabular}

Source: National Science Board, 2012, from Appendix Table 6-45.

TABLE 21

PATENT APPLICATIONS

\begin{tabular}{rrrrrrrrrrr}
\hline & \multicolumn{4}{c}{ Latin America and Caribbean } & \multicolumn{3}{c}{ East Asia and Pacific w/o China } & \multicolumn{2}{c}{ China } \\
\cline { 2 - 11 } & Resident & Total & $\begin{array}{c}\text { Resident/ } \\
\text { Total }\end{array}$ & Resident & Total & $\begin{array}{c}\text { Resident/ } \\
\text { Total }\end{array}$ & Resident & Total & $\begin{array}{c}\text { Resident/ } \\
\text { Total }\end{array}$ \\
\hline 1985 & 3019 & 12996 & 23 & 203 & 4434 & 5 & 4065 & 8558 & 47 \\
1990 & 4419 & 17630 & 25 & 370 & 6327 & 6 & 5832 & 10137 & 58 \\
1995 & 4150 & 19121 & 22 & 669 & 13700 & 5 & 10011 & 18699 & 54 \\
2000 & 4855 & 43890 & 11 & 1,147 & 20134 & 6 & 25346 & 51906 & 49 \\
2005 & 5836 & 44138 & 13 & 8181 & 27588 & 30 & 93485 & 173327 & 54 \\
2009 & 5012 & 40590 & 12 & 11291 & 30428 & 37 & 229096 & 314604 & 73 \\
\hline
\end{tabular}

Source: World Development Indicators, on-line, accessed October 28, 2013. 
One of the factors that make it difficult for companies to take risks and innovate is the limited access to finance capital. Capital markets in Latin America are very shallow in comparison to other regions. In 2012, domestic credit to the private sector amounted to 48 percent of GDP in Latin America. That compares with an average of 83 percent for middle-income countries and 120 percent for the developing world in East Asia and the Pacific

Another important factor shaping the incentive structure is the exchange rate. The commodity price boom and the influx of foreign capital in recent years have led to a considerable appreciation of the real exchange rate in many Latin American countries as well as to great volatility of exchange rates (Cimoli, Porcile, Calza 2013, Ffrench-Davis 2012, Gallagher et al. 2011). Appreciation and volatility are not conducive to the conceptualization and implementation of medium-terms plans for innovation. 


\section{Lessons from other latecomers in the catch-up process}

When governments in Latin America liberalized markets in the 1980s, they were intent on tackling the problem of inefficiency in the private and public sectors. Trade liberalization was to expose domestic companies to international market competition and force them to become efficient. Privatization and a general roll-back of government activities was thought to eliminate rent-seeking and unleash the productive potential of the private sector. Foreign investment was expected to generate technological spillovers to domestic companies. And policies for the productive sector aimed to enhance the working of markets, not to support firm learning. However, as the previous section has shown, reality has turned out differently. Neoliberal policies succeeded in re-establishing macro stability, but they did a poor job at advancing the social and firm-level capabilities needed for broad-based growth-enhancing structural change and productivity growth.

This section of the paper takes a look at what we can learn from other latecomers' experiences in advancing productive capabilities towards more innovation-incorporating production. There is a vast literature on structural change, dynamic upgrading, and the bases for successful transformation of the Asian Tigers: South Korea, Taiwan, Hong Kong, and Singapore (e.g., Amsden 2001, Wade 1990). In today's global world, developing countries can no longer restrict trade and foreign investment to provide a learning space for local producers, as South Korea and Taiwan did in the past as well as Latin America during the era of import substitution. Countries now operate under a substantially more liberal regime of international economic policies, nationally and globally.

Below I discuss lessons from China's experience and from a group of small latecomers. It is important to look at China's performance, because it is the middle-income country with the most successful growth-enhancing structural change and high growth in recent history. While some of China's policies are transferable to other countries, other factors are unique to the Chinese context. The size of the country provides opportunities and leverage for bargaining in the international arena that other countries simply do not have. And the existence of an authoritarian regime has made it easier and faster to implement a pro-development agenda. That does not make authoritarianism preferable to democratic processes, where processes of decision-making and deliberation take longer. But the political system is 
part of the explanation for the rapid accumulation of social and firm level capabilities in China compared to other middle-income countries in Latin America and elsewhere.

Most middle-income countries do not have China's size advantages. They are small in size which entails a particular set of challenges. Therefore I also discuss key lessons from the upgrading experience in five small latecomers which operated under liberal trade and investment policies: Chile, the Dominican Republic, Jordan, Ireland, and Singapore.

\section{A. Lessons from China's experience}

For the last two decades, Latin American countries have mainly followed the free-market policies of the Washington Consensus. China, in contrast, has pursued a strategy of strategic investments in the expansion of domestic knowledge-based assets and of controlled market liberalization trade and foreign investment. In many ways, the development strategy behind the Chinese success story is the very antithesis of the Washington Consensus.

Most of the key tenets of the Chinese strategy are not new. With rare exceptions, latecomers in the development process have caught up using protectionist measures and strategic government interventions to develop national technological capabilities broadly and in targeted sectors (e.g. Chang 2008, Reinert 2007, Rodrik 2007, Amsden 2001, Wade 1990). In the case of China, the government moved strategically to promote the domestic semiconductor industry and the automobile industry. In 1994, China established explicit industrial policies for the development of the automobile industry, consolidating existing companies, increasing tariff protection, requiring foreign investors to establish joint ventures with domestic companies and transfer certain technologies.

What is arguably new in the Chinese model, compared to the earlier Asian Tigers, is the large emphasis on promoting domestic R\&D at an earlier stage in the development process than had been the case for the Asian Tigers. Deliberate promotion of specific sectors, large-scale promotion of R\&D in high-tech areas, and technology transfer requirements for foreign investors have been at the heart of China's strategy of foster domestic knowledge-based assets in a context of increased, but managed, economic openness (Lee et al. 2011, World Bank et al. 2012, Zeng and Williamson 2007). In China's current Five Year Plan (2011-15), innovation is a key priority. The country's Science and Technology Plan aims for an increase in the R\&D intensity to 2.5 percent by 2020 .

A recent survey of innovation activities in China suggests that China is on its way of becoming a regional and global hub for innovation. Forty percent of the TNC affiliates and 50 percent of the Chinese companies surveyed stated that they are developing products in China for markets outside of China (Benelux Chamber of Commerce et al. 2012, 7).

The point is not that China got everything right. The country is facing several critical challenges that it will need to address in the coming years. China's growth has been accompanied by a substantial deterioration in the distribution of income, generally in favor of the city versus the countryside, coastal areas versus the interior, and the South versus the North. The Gini index rose from 27.7 in 1984 to 42.1 in 2009. China's high economic growth has also resulted in dramatic environmental deterioration. Indeed, economic growth would be much smaller - some think negligible - if we factored in environmental costs (Sims Gallagher 2009). The economic structure is seriously imbalanced and warrants a significant shift from investment to domestic consumption. And the high debt of local governments is the source of considerable concern about the possibility of a debt crisis.

Rather, the point is that the development success stories of the past and most recently of China were based on a collaboration between the public and private sectors where the government played an active role in shaping and implementing strategic priorities aimed at moving production up the value chain. China's size has given it advantages and opened policy options that are not available for most other latecomers, e.g., the government's ability to leverage access to the domestic market for technology transfer by TNC affiliates. 
Most latecomers are not large like China, or even large like Brazil. Most latecomers are small. In 2011, 58 percent of middle-income countries had less than 10 million people; 11 percent had between 10 and 20 million people and 17 percent between 20 and 50 million people. Only 14 percent of the countries had a population of more than 50 million. Thus it is useful to look also at the upgrading experiences of small countries over the last 30 years to explore what lessons can be learned.

\section{B. Lessons from small latecomers}

A major recent study provides a detailed analysis of the upgrading experiences in five small latecomers under a liberal policy regime for trade and foreign investment: Chile (Perez Caldentey 2012), the Dominican Republic (Sánchez-Ancochea 2012), Ireland (Paus 2012b), Jordan (Abugattas 2012), and Singapore (Prime 2012). The comparative case studies suggest six important lessons.

First, income convergence does not necessarily imply capability convergence. The case studies show that income convergence is not necessarily a reflection of upgrading and advancement in technological capabilities. Singapore is the only country with on-going broad-based upgrading towards more sophisticated activities. Ireland was moving towards broad-based upgrading during the 1990s, but subsequent advances were derailed during the 2000s, when growth was driven and ultimately subverted by a consumption and real estate bubble. Chile, Jordan, and the Dominican Republic have not had broadbased upgrading, though all developed "pockets of excellence": a pharmaceutical sector in Jordan, some medical devices, electronics and tourism in the Dominican Republic, and aqua/forest/agriculturallybased products in Chile.

Second, the distinguishing characteristic between the countries in the sample that achieved broadbased upgrading and those that did not was a deliberate government focus on upgrading and sustained and broad-based policy efforts to advance social capabilities in line with the expansion of firm level upgrading. In Singapore, the government has played a key role in building social capabilities and updating them continuously to meet the needs of foreign companies. The government has been proactive as well as reacting to problems when needed, but always with clear strategic targets. Successive Irish governments combined a free trade and foreign investment regime with pro-active, interventionist policies, sometimes serendipitously and other times intentionally. Like Singapore, Ireland targeted foreign direct investment in higher-tech areas, which allowed production to jump in the product space. The governments in Chile, the Dominican Republic, and Jordan, on the other hand, were relying primarily on a market-led process to generate growth. When the countries embarked on Washington Consensus policies - Chile starting in 1973, the Dominican Republic in 1984, and Jordan in 1991stability and allocative efficiency were the top goals on the agenda, not broad-based capability-building. Nonetheless, the pockets of upgrading excellence in these countries confirm on a sectoral level the findings for Singapore and Ireland on a broader level: pro-active government policies to advance social and firm-level capabilities.

Third, FDI does not automatically contribute to the advancement of technological capabilities in the host countries. In all five countries, governments envisioned foreign direct investment to play a key role in the country's overall growth and development. But the actual impact of FDI on upgrading varied greatly. Singapore and Ireland made very deliberate efforts to attract FDI into increasingly more hightech sectors and then into more sophisticated activities within those sectors. Jordan and the Dominican Republic succeeded in attracting FDI in the apparel sector, though in recent years the Dominican Republic has also drawn FDI in medical devices. In Chile, FDI went primarily into the natural resource sector. It was only in 2000 that Chile established a foreign investment agency (INVEST CHILE) with the purpose of attracting technology-intensive foreign investment.

But even the governments that used targeted foreign direct investment policies differed in their strategic sense of the development of local firm upgrading. It was not until the late 1980s, after two decades of policy focus on FDI, that the Irish government established institutions and support policies to promote local firm capabilities. In Singapore, the lack of local firm upgrading was recognized in the 1990s and has been a target of policies since then. Chile, Jordan, and Chile did not adopt special policies to promote linkages. Their policies to promote local firm capabilities in all sectors have focused 
primarily on the provision of credit to small and medium-sized enterprises, though, in all three cases, with insufficient levels of funding.

Fourth, fiscal resources are needed to support the development of social capabilities, local firm upgrading and TNC movements up the value chain. Some of the countries in the project benefited from special conditions that enabled them to broaden the fiscal space. Ireland benefited from EU structural funds. Singapore combined forced savings via the retirement scheme with incentives to increase savings voluntarily in the private sector. Jordan has received aid inflows up to 25 percent of GDP due to the geostrategic location of the country. Chile, more recently, has taken advantage of the copper price boom to extract additional revenue to support the current expansion of R\&D.

Fifth, macroeconomic variables have to provide an incentive structure favorable to upgrading and innovation. The combination of macro stability and incentives for upgrading worked very well in the case of Singapore. But that was not the case in the other countries, especially when the primary focus was on price and fiscal stability. In Jordan, the long-time fixed exchange rate vis-à-vis the US dollar (since 1995) has constituted a serious obstacle to upgrading, as it cheapened imports (on top of the tariff liberalization) and made competitiveness in international markets more difficult. In Chile, since the crisis of the early 1980s, successive governments have privileged nominal macro stability and permitted exchange rate appreciation to the detriment of local producers. Adoption of the Euro in 2001 led to a drastic decline of interest rates for Ireland. That, together with lax supervision of the Irish banking system and populist policies, produced a set of incentives that favored short-term gains in the real estate and financial sectors over long-term development of innovation activities.

Sixth, the case studies demonstrate that time and location matter. Singapore has benefited from its location in Asia and its timing in terms of promoting manufactured exports just as the electronics industry began to build global production networks. Ireland's membership in the European Union resulted in a substantial net transfer of funds from Brussels. Closeness to the United States has allowed the Dominican Republic to attract foreign investment for exports since the mid-1980s. On the other hand, however, the United States has consistently imposed rules that reduce the chances for systematic upgrading. The Caribbean Basin Initiative required countries to use American inputs, while the Central American Free Trade Agreement (DR-CAFTA) reduced policy space and set wrong policy priorities. And Jordan's geo-strategic location was the reason for huge inflows of foreign grants, up to 25 percent of GDP. While these funds were used in part for the advancement of social capabilities, they were not used strategically to support firm level upgrading. 


\section{Conclusions and challenges}

Latin America's higher economic growth between 2003 and 2007 does not provide grounds for complacency. We have seen that countries in the region have serious gaps in social and firm level capabilities compared to other middle-income countries, especially China. Thus many countries find themselves in a situation where they can no longer compete in labor-intensive, standardized commodities, but productive capabilities have not advanced broadly enough to allow them to compete in higher value added activities to a significant extent.

In a global context where the pressures to innovate continue to rise, it is imperative for countries to rise to the productivity challenge or risk competing on the basis of declining wages. The focus on the middle-income trap highlights this dilemma and entails a call for policy action. In this paper I have argued that a capabilities-focused strategy offers the only promise for shifting production towards more knowledge-intensive activities and avoid become trapped at the middle-income level.

Governments have to pay attention to the co-evolution of social and firm level capabilities so as to enable sophisticated and higher value added production. The implementation of such a strategy does not mean that countries have to do everything at the same time. But it does mean that action in one area has to be undertaken with the understanding that it forms part of a coherent whole and that actions in other areas have to follow. Whether a country will avoid the trap depends on the ability of public and private decision-makers to overcome the most binding constraint, one after another.

There are four major challenges that affect all Latin American countries to varying degrees. They speak to the context, constraints, and need for coordination in the implementation of a productive capabilities-based strategy in Latin America.

\section{A. Cohesive productivist policies to address the structural heterogeneity in production}

During the 2000s, the disappointing results of Washington Consensus policies for structural change and productivity growth became increasingly obvious and widely discussed in Latin America (Reinhardt and Peres 2000, Rodrik 2001). As a result, industrial policies re-emerged in the region (Peres 2011), first slowly, but recently increasingly more explicitly. Mexico's National Development Plan 2013-2018, 
released in June 2013, advocates the use of industrial policy to achieve development (Moreno-Brid 2013). Brazil has been a major exception all along, never embracing Washington Consensus policies as extensively as its southern neighbors and all along maintaining its state development bank (BNDES) as well as more explicit and targeted industrial policies.

But in many countries industrial policies have been piece-meal and not part of an overall strategic focus on the advancement of technological capabilities. Policies tend to lack transparency and accountability (see Almeida and Schneider, 2012, on Brazil), and their effectiveness is rarely evaluated (Peres 2011). They frequently lack continuity from one administration to the next, and support policies are often not well coordinated across agencies so that they sometimes worked at cross-purposes (Paus 2011, Peres 2011). In addition to aiming for more cohesion, continuity and transparency, productivist policies must not just be horizontal, but also vertical. The main reasons are that social and firm level capabilities are often industry-specific, their advancement requires coordination, and resources are scarce. A key issue of debate is how industries or clusters are chosen, with some arguing that the targets should be close to existing comparative advantages and others suggesting that they may or must be further apart in the product space (Chang and Lin 2009).

Productivist policies have to be cognizant of the highly dualistic production sector. A limited number of firms have become competitive internationally, while a huge number of small and micro enterprises produce for the domestic market and face profound challenges to compete (Pages-Serra 2010). Some policies need to encourage innovation and high-tech activities for some firms and sectors, and others have to support the integration of micro and small enterprises at the low end of the value chains.

As a result of innovation and high productivity growth, employment in manufacturing has been on the decline around the world: in Latin America, in developed countries and even in China. That makes it particularly important to think creatively about how and where jobs can be created that can offer workers a decent living.

\section{B. Fiscal resources to support the advancement of social and firm level capabilities}

Active government support for upgrading requires resources, whether for expenditures on education and infrastructure, the build-up of a national innovation system, tax incentives in different areas, or direct support for firm learning. Resources are urgently needed to address the infrastructure challenges in the region. The poor road infrastructure makes the time and cost of national and regional transportation substantially higher than in other countries, and it constitutes a significant barrier to competitiveness and regional integration.

In many Latin American countries, tax ratios are significantly below the average for countries at that income level. In Mexico, for example, tax revenue constitutes only 12 percent of GDP (MorenoBrid 2013). Raising resources at the expense of macro stability is not a viable option. Increasing tax efficiency, finding new sources of tax revenue, or tapping external sources are the sources that governments will have to use (Abugattas and Paus 2010). The commodity price boom has offered a unique opportunity for natural resource exporters to tax the windfall profits and use the proceeds for the advancement of technological capabilities. Chile, for example, has taken advantage of the copper price boom to extract additional revenue to support the expansion of R\&D (Pérez Caldentey 2012). But countries without natural resources, e.g., all of Central America and Mexico, have to find different ways to raise revenue and overcome the political challenges that entails.

External financing is another area that needs to be explored as a possible source for funding. Currently, eligibility for official development assistance is based on per capita income. But that is only one way to distinguish among developing countries, as we saw in this paper. ECLAC $(2012,2011)$ and UNDP et al. (2013) argue that there is no reason to privilege the income measure over other indicators that may be equally important and that may constitute binding constraints at the country level. ECLAC (2012) offers creative suggestions for external financing mechanisms, ranging from program aid where co-responsibility replaces conditionality to an expansion of 'Aid for Trade' to global taxes on financial transactions. 


\section{A cohesive incentive structure to support the advancement of local firm capabilities}

Under Washington Consensus policies, many Latin American governments offered an incentive structure that favored foreign investors. Tax exemptions of various kinds have been common fare to attract foreign investors into export processing zones. The minimum capital requirements for investment in the zones are often too high for local firms, thus creating an uneven playing field, at the very time that the technological backwardness of local firms and their need to learn would warrant that the field be tilted in their favor.

In recent years, several Latin American countries have established tax incentives for R\&D, for both local and foreign producers. Some governments have been very aggressive and established 'super deductions.' Brazil offers incentives equivalent to 170 percent of eligible R\&D expenditures, and Chile's incentives go up to 50 percent (Deloitte 2012). Brazil's Inovar Auto incentive program offers an example of creative incentive structuring to promote innovation and upgrading, without increasing government expenditures. In addition to public sector incentives, bank lending to the private sector has to grow. Local firms in Latin America need to have better access to banking capital.

One of the key relative prices influencing firm decisions and competitiveness is the exchange rate. When the real exchange rate appreciates (as happened in a number of Latin American countries during the last decade), relative prices provide a disincentive for exporting and an obstacle for international competitiveness. Overvalued exchange rates frequently mitigate against learning and capability accumulation (Cimoli, Porcile, Calza, 2013). In addition, the volatility of the exchange rates induces macro instability, which calls for the inclusion of capital controls in governments' policy tool kits (Foxley 2012, Gallagher et al. 2011).

\section{Implementation challenges}

Institutionalized private-public collaborative efforts are necessary to determine - in the country-specific context - the most binding gap and the specific productive sectors that should be targeted for the development of new comparative advantages. Here many Latin American countries have already gained some valuable experience during the neo-liberal period. Getting the process right is key to engendering virtuous dynamics in the creation of the targeted new comparative advantages (e.g. Hausmann and Rodrik 2006, Rodrik 2007).

The implementation of a capabilities-focused strategy also requires institutional capacity. Most countries do not have a merit-based professional and technically capable civil service. Devlin and Moguillansky (2012) identify that weakness as the Achilles heel of industrial policy in Latin America.

This paper has not discussed the political challenges for implementing a capability-focused strategy. And they may be the most vexing ones in some countries. After a long process of deindustrialization where many producers in the formal sector were forced out of business or sold their businesses to dedicate themselves to importing, the big question is whether there is the political will to pursue a capabilities-focused strategy. In other words, is there is a dominant coalition that is interested in pushing for such a strategy and in raising the needed resources?

Currently, policy making in many countries tends to be dominated by ministries of finance and not by those responsible for the real sector (Devlin and Moguillansky 2011, 106). Foxley (2012) argues that inequality is another area in which political will is critical for change. He emphasizes that the high inequality of income and opportunity in Latin America make it very difficult to achieve the consensus needed for a new strategy, but that lack of further reduction in equality may generate a trap of social and political instability, and thus low economic growth. 
In a study of Ireland, Singapore and Finland, Yusuf and Nabeshima (2012) argue that an important common elements among these latecomers was a consensus among key stakeholders about the development strategy to be pursued. That is the challenge for Latin American countries. Fortunately, there are some areas, particularly in education and infrastructure, where policy interventions can serve the dual purpose of increasing equality of opportunity as well as facilitating a shift towards growthenhancing structural change (Paus 2013). Identifying such win-win scenarios will make it easier to find consensus around a new strategy. 


\section{Bibliography}

Abramovitz, Moses. 1986. "Catching up, Forging Ahead, and Falling Behind," The Journal of Economic History, 46, 2, 385-406.

Abugattas, Luis. 2012. "Jordan: Model Reformer without Upgrading?," Studies in Comparative Economic Development, 47, 231-253.

Abugattas, Luis and Eva Paus. 2010. "Mobilizing Public Resources for a New Development Strategy in the Age of Globalization. The Fiscal Space Dilemma in Latin America," in Shahrukh Khan and Jens Christiansen. Eds. Markets as Means Rather than Masters. Towards a New Developmentalism. Routledge, 2010.

Aiyar, Shekhar, Romain Duval, Damien Puy, Yiqun Wu, and Longmei Zhang. 2013. "Growth Slowdowns and the Middle-income trap," International Monetary Fund Working Paper WP/13/71.

Agénor, Pierre-Richard and Otaviano Canuto. 2012. "Middle-Income Traps, "World Bank, Policy Research Working Paper 6210.

Almeida, Mansueto and Ben Ross Schneider. 2012. "Globalization, Democratization, and New Industrial Policies in Brazil," Korean Development Institute, Seoul.

Amsden, Alice. 2001. The Rise of "The Rest." Challenges to the West from Late-Industrializing Economies. Oxford, New York: Oxford University Press.

Benelux Chamber of Commerce, China Europe International Business School, Wenzhou Chamber of Commerce and Booz\&Co. 2012. Innovation. China's Next Advantage? 2012 China Innovation Survey.

Cadot, Olivier, Carrère, Céline, and Vanessa Strauss-Kahn. 2009. "Export Diversification: What's behind the Hump?” CERDI, Working Paper E 2009.34, http://publi.cerdi.org/ed/2009/2009.34.pdf.

Calderón, César and Luis Servén. 2012. "Infrastructure in Latin America," World Bank Policy Research Paper 5317.

CEPAL. 2010. "Aportes para un diagnostico sobre las restricciones al desarrollo y a una integración económica más profunda," Boletín Fal No 287. Santiago, Chile: CEPAL.

Chen, Yougang, Stefan Matzinger, and Jonathan Woetzel. 2013. "Chinese Infrastructure. The Big Picture," McKinsey Quarterly. 3, 8-15.

Cimoli, Mario, Gabriel Porcile and Elisa Calza. 2013. "Still Blowin' in the Wind. Industrial Policy, Distorted Prices and Implicit Reciprocity," in Eva Paus. ed. Getting Development Right. Structural Transformation, Inclusion, and Sustainability in the Post-Crisis Era. New York and London: Palgrave Macmillan, 41-60.

Cimoli, Mario, Gabriel Porcile and Sebastián Rovira. 2010. "Structural Change and the BOP constraint: Why Did Latin America Fail to Convergence," Cambridge Journal of Economics. 34, 389-411. 
Cimoli, Mario, Giovanni Dosi, and Joseph E. Stiglitz. Eds. 2009. Industrial Policy and Development. The Political Economy of Capabilities Accumulation. Oxford: Oxford University Press.

Chang, Ha-Joon and Justin Lin. 2009. "Should Industrial Policy in Developing Countries Conform to Comparative Advantages or Defy it? A Debate Between Justin Lin and Ha-Joon Chang", Development Policy Review, 27(5): 483-502.

Chang, Ha-Joon. 2008. Bad Samaritans. The Myth of Free Trade and the Secret History of Capitalism. New York: Bloomsbury Press.

Cornell University, INSEAD, and WIPO. 2013. The Global Innovation Index 2013: The Local Dynamics of Innovation. Geneva, Ithaca, and Fontainebleau.

Dahlman, Carl J. 2009. "Growth and Development in China and India: The Role of Industrial Policy in Rapid Catch-up," in Mario Cimoli, Giovanni Dosi, and Joseph Stiglitz. Eds. Industrial Policy and Development. The Political Economy of Capability Accumulation. Oxford: Oxford University Press, 303-335.

Deloitte.2012. 2012 Global Survey of R\&D Tax Incentives. http://www.nam.org/ /media/0C454F85FE324 C678330C1CCA0E92168/Global_RD_Survey_September_2012_FINAL.pdf.

Devlin, Robert and Graciela Moguillansky. 2011. Breeding Latin American Tigers. Operational Principles for Rehabilitating Industrial Policies. Santiago, Chile and Washington, D.C: ECLAC and the World Bank. 2012. "What's New in the New Industrial Policy in Latin America"? World Bank. Policy Research Paper 6191.

Dinh, Hinh T., Thomas G. Rawski, Ali Zatar. Lihong Wang, Eleonora Mavroedi. 2013. Tales from the Development Frontier. How China and Other Countries Harness Light Manufacturing to Create Jobs and Prosperity. Washington, D.C.: World Bank.

ECLAC. 2010. Time for Equality. Closing Gaps, Opening Trails. Santiago, Chile: ECLAC. 2012. Financing for Development and Middle-Income Countries: New Challenges. Santiago, Chile: ECLAC. 2012. Middle-Income Countries. A Structural Gap Approach. Santiago, Chile: ECLAC.

Eichengreen, Barry, Donghyun Park and Kwanho Shin. 2013. "Growth Slowdowns Redux: New Evidence on the Middle-Income Trap,” NBER Working Paper Series, WP 18673.

2011. "When Fast-Growing Economies Slow Down: International Evidence and Implications for China," NBER Working Paper Series, WP 16919.

Felipe, Jesus, Arnelyn Abdon and Utsav Kumar. 2012. "Tracking the Middle-income trap: What Is It? Who Is in It, and Why?" Levy Economics Institute of Bard College, Working Paper No. 715, April.

Ffrench-Davis, Ricardo. 2012. "Empleo y Estabilidad Macroeconómica Real: El Rol de los Flujos Financieros en América Latina," Universidad de Chile, Departamento de Economía, Documentos de Trabajo 349.

Foxley, Alejandro. 2012. La Trampa del Ingreso Medio. El desafío de esta década para América Latina. Santiago, Chile: CIEPLAN.

Freeman, Richard. 2007. "The Challenge of the Growing Globalization of Labor Markets to Economic and Social Policy," in Eva Paus. ed. Global Capitalism Unbound. Winners and Losers from Offshore Outsourcing. New York and London: Palgrave Macmillan, 23-39.

Gallagher, Kevin and Roberto Porzecanski. 2010. The Dragon in the Room: China and the Future of Latin American Industrialization. Stanford: Stanford University Press.

Gallagher, Kevin, Stephany Griffith-Jones and José Antonio Ocampo. 2011. "Capital Account Regulations for Stability and Development: A New Approach," The Frederick S. Pardee Center for the Study of the Longer Range Future, Issue Paper 22.

Gill, Indermit and Kharas, Homi. 2008. An East Asia Renaissance. Ideas for Economic Growth. Washington, D.C.: World Bank.

Hausmann, Ricardo, Jason Hwang, and Dani Rodrik. 2007. "What You Export Matters," Journal of Economic Growth, 12, 1-25.

Hausmann, Ricardo and B. Klinger. 2007. "The Structure of the Product Space and the Evolution of Comparative Advantage," Working Paper No. 146, Cambridge, MA: Harvard University Center for International Development.

Hausmann, Ricardo and Dani Rodrik. 2006. "Doomed to Choose: Industrial Policy as Predicament," http://ksghome.harvard.edu/ rodrik/doomed.pdf.

Hidalgo, C., B. Klinger, A.L. Barabasi, and R. Hausmann. 2007. "The Product Space Conditions the Development of Nations," Science, 317, 482-487.

Humphrey, John and Hubert Schmitz. 2000. "Governance and Upgrading: Linking Industrial Clusters and Global Value Chain Research," Institute of Development Studies, University of Sussex, Working Paper No. 120.

ICCT (International Council on Clean Transportation). 2013. "Brazil's Inovar-Auto Incentive Program," Policy Update. February, www.theicct.org. 
Imbs, Jean and Romain Wacziarg. 2003. "Stages of Diversification,” American Economic Review 93, 1, 63-86.

International Labor Organization. 2013. "La Trampa del Empleo Sumergido en América Latina," Sept 30, http://www.ilo.org/americas/oficina-regional/direcci\%C3\%B3n-regional/WCMS 222578/lang--es/index.htm.

Jankowska, Anna, Arne Nagengast and José Ramón Perea. 2012. "The Product Space and the Middle-income trap: Comparing Asian and Latin American Experiences," OECD Development Centre, Working Paper No. 311.

Jenkins, Rhys. "Chinese Competition and Brazilian Exports of Manufactures," Oxford Development Review. Forthcoming.

Kharas, Homi and Harinder Kohli. 2011. "What is the Middle-income trap, Why Do Countries Fall into It, and How Can It Be Avoided?" Global Journal of Emerging Market Economies, 3, (3), 281-289.

Kroll, Henning and Andrea Zenker. 2009. "An Analysis of the R\&D Expenditures at Regional Level in Light of the 3\% Target," European Commission. Directorate General for Research.

$\mathrm{http} / / /$ ec.europa.eu/research/innovation-union/pdf/analysis_of the_development_of_r_d_expenditure.pdf.

Lall, Sanjaya. 1992. "Technological Capabilities and Industrialization," World Development 20, 2, $165-186$. 2000. "The Technological Structure and Performance of Developing Country Manufactured Exports 1985-1998," Oxford Development Studies 28, 3, 337-369.

2001. Competitiveness, Technology and Skills. Cheltenham, UK and Northamption, MA: Edward Elgar.

Lee, Keun. 2009. "How Can Korea be a Role Model for Catch-up Development? A Capability-Based View," World Institute for Development Economics Research, United Nations University, Research Paper No. 2009/34.

2013. Schumpeterian Analysis of Economic Catch-up: Knowledge, Path Creation and the Middleincome trap. Cambridge and New York: Cambridge University Press.

Lee, Keun, Mansoo Jee, and Jong-Hak Eun. 2011. “Assessing China’s Economic Catch-up at the Firm Level and Beyond: Washington Consensus, East Asian Consensus and the Beijing Model," Industry and Innovation. 18, 5, 487-507.

Lin, Justin Yifu. 2012. The Quest for Prosperity. How Developing Countries Can Take off. Princeton and Oxford: Princeton University Press.

Lin, Justin Yifu and Volker Treichel. 2012. "Learning from China's Rise to Escape the Middle-Income Trap. A New Structural Economics Approach to Latin America," World Bank. Policy Research Working Paper 6165.

Lundvall, Bengt-Ake, Bjoern Johnson,Esben Sloth Andersen, Bent Dalum, 2002, "National Systems of Production, Innovation and Competence Building," Research Policy 31, 213-231.

McMillan Margaret and Dani Rodrik. 2011. "Globalization, Structural Change and Productivity Growth," NBER Working Paper 17143, June.

Mkandawire, Thandika. 2013. "Social Policy and the Challenges of the Post-Adjustment Era," in Eva Paus. ed. Getting Development Right. Structural Transformation, Inclusion, and Sustainability in the PostCrisis Era. New York and London: Palgrave Macmillan, 61-82.

Moreno-Brid, Juan Carlos. 2013. “Industrial Policy: A Missing Link in Mexico’s Quest for Export-Led Growth," Latin American Policy 4,2, 216-237.

National Science Board. 2012. Science and Engineering Indicators. Arlington, VA: National Science Foundation.

Ocampo, Jose Antonio, Codrina Rada and Lance Taylor. 2009. Growth and Policy in Developing Countries. A Structuralist Approach. New York: Columbia University Press.

Ocampo, José Antonio and Rob Vos. 2008. Uneven Economic Development. London and New York: Zed Books.

OECD. 2013. PISA 2012 Results in Focus. www.oecd.org/pisa.

Ohno, Kenichi. 2009. The Middle-income trap. Implications for Industrialization Strategies in East Asia and Africa. GRIPS Development Forum, National Graduate Institute for Policy Studies, Japan.

Pages-Serra, Carmen. Ed. 2010. The Age of Productivity. Transforming Economies from the Bottom Up. Washington, D.C.: Inter-American Development Bank.

Paus, Eva. 2005. Foreign Investment, Development and Globalization. Can Costa Rica Become Ireland? New York: Palgrave-Macmillan.

2009. "The Rise of China: Implications for Latin American Development," Development Policy Review. 2009, 27 (4): 419-56.

2011. "Latin America's Middle-income trap," Americas Quarterly. Winter, 71-76.

2012a. "Confronting the Middle-income trap. Insights from Small Latecomers," Studies in Comparative International Development 47(2):115-138.

2012b. "The Rise and Fall of the Celtic Tiger. When Populism Trumps Developmentalism," Studies in Comparative International Development, 47, 161-184.

2013. Ed. Getting Development Right. Structural Transformation, Inclusion, and Sustainability in the Post-Crisis Era. New York and London: Palgrave Macmillan. 
2014. "Industrial Development Strategies in Costa Rica: When Structural Change and Domestic Capability Accumulation Diverge," in Irmgard Nubler, José Manuel Salazar-Xirinachs and Richard Kozul-Wright. eds. Industrial Policy for Economic Development: Lessons from Country Experiences. Geneva: International Labour Organization, forthcoming.

Paus, Eva, Nola Reinhardt and Michael Robinson. 2003. "Trade Liberalization and Productivity Growth in Latin American Manufacturing," Journal of Policy Reform 6, 1, 1-16.

Peres, Wilson. 2011. "Industrial Policies in Latin America," United Nations University. World Institute for Development Economics Research. Working Paper No.2011/48.

Pérez Caldentey, Esteban, 2012, "Income Convergence, Capability Convergence, and the Middle-income trap: An Analysis of the Case of Chile," Studies in Comparative International Development. 47, 185-207.

Perrotti, Daniel E. and Ricardo J. Sánchez. 2011. "La brecha de infraestructura en América Latina y el Caribe," CEPAL, División de Recursos Naturales e Infraestructura. 153.

Pietrobelli, Carlo and Roberta Rabellotti. Eds. 2006. Upgrading to Compete. Global Value Chains, Clusters, and SMEs in Latin America. Washington, D.C.: Inter-American Development Bank.

Prime, Penelope. 2012. "Using FDI to Stay Ahead: The Case of Singapore," Studies in Comparative International Development, 47, 139-160.

McMillan Margaret and Dani Rodrik. 2011. "Globalization, Structural Change and Productivity Growth," NBER Working Paper 17143, June.

Reinert, Erik. 2007. How Rich Countries Got Rich and Why Poor Countries Stay Poor. New York: Public Affairs.

Reinhardt, Nola and Wilson Peres. 2000. 'Latin America's New Economic Model: Micro Responses and Economic Restructuring', World Development. Vol. 28, p. 1543-1566.

Robertson, Peter and Longfeng Ye. 2013. "On the Existence of the Middle-income trap," Business School, University of Western Australia, Discussion Paper 13.12.

Rodrik, Dani. 2011. "The Future of Economic Convergence," Paper presented at the Jackson Hole Symposium of the Federal Reserve Bank of Kansas City, Aug 25-27.

2007. One Economics. Many Recipes. Globalization, Institutions and Economic Growth. Princeton, NJ: Princeton University Press.

2001. "The Global Governance of Trade as If Development Mattered," mimeo, July.

Sabel, Charles, Eduardo Fernández-Arias, Ricardo Hausmann, Andrès Rodríguez-Clare and Ernesto Stein. 2012. Export Pioneers in Latin America. Washington, D.C. and Cambridge, MA: Inter-American Development Bank and David Rockefeller Center for Latin American Studies.

Sánchez-Ancochea, Diego. 2012. "A Fast Herd and a Slow Tortoise? The Challenge of Upgrading in the Dominican Republic," Studies in Comparative International Development. 47, 208-230.

Shanghai Daily. 2011. "How China Can Avoid Trap of Middle Income,"http://www.shanghaidaily.com/ article/print.asp?id=469178.

Shapiro, Helen and Lance Taylor. 1990. “The State and Industrial Policy”, World Development, 18, 6, 861-878.

Sims Gallagher, Kelly. 2009. “The Voracious Dragon: Environmental Implications of China's Rising Energy Consumption," in Eva Paus, Penelope Prime, Jon Western, eds. Global Giant. Is China Changing the Rules of the Game? New York and London: Palgrave Macmillan, 93-111.

UNDP, Ministry of Foreign Affairs, Korea Institute for International Economic Policy. 2013. Challenges of the Middle-income countries. Seoul Debates 2013. Seoul: UNDP, MOFA, KIEP.

UNIDO. 2009. Industrial Development Report 2009. Vienna: UNIDO. 2011. Industrial Development Report 2011. Vienna: UNIDO.

Wade, Robert. 1990. Governing the Market. Economic Theory and the Role of Government in East Asian Industrialization. Princeton: Princeton University Press.

World Bank. 2010. East Asia and Pacific Economic Update 2010. Vol. 2, Washington, D.C.: World Bank.

World Bank. Development Research Center of the State Council, The People's Republic of China. 2012. China 2030. Building a Modern, Harmonious, and Creative High-Income Society.

World Economic Forum. 2013. The Human Capital Report. Geneva: World Economic Forum.

Yusuf, Shahid and Kaoru Nabeshima. 2009a. "Can Malaysia Escape the Middle-income trap?" World Bank Development Research Group. Policy Research Working Paper 4971.

2009b. Tiger Economies under Threat. A Comparative Analysis of Malaysia's Industrial Prospects and Policy Options. Washington: The World Bank.

2010. Changing the Industrial Geography in Asia. The Impact of China and India. Washington, D.C.: World Bank.

Zeng, Ming and Peter J. Williamson. 2007. Dragons at Your Door. Boston: Harvard Business School Press.

Zoellick, Robert, 2011. "The Big Questions China has to Answer,” Financial Times. Sept 1. 


\title{
Series:
}

\section{E $\complement$ L A $\complement$ Financing for Development}

\section{Issues published}

\author{
A complete list as well as pdf files are available at \\ www.eclac.org/publicaciones
}

250. Latin America and the middle-income trap (LC/L.3854), 2004.

249. Right to health in Latin America: beyond universalization (LC/L.3647), 2013.

248. El sistema financiero en América Latina y el Caribe: una caracterización (LC/L.3746), 2013.

247. Comercio exterior, cadenas globales de producción y financiamiento: conceptos y relevancia para América Latina y el Caribe (LC/L.3745), 2013.

246. Macroeconomics for Development in Latin America and the Caribbean: Some new considerations on counter cyclicality (LC/L.3744), 2013.

245. Sistema de pagos transnacionales vigentes en América Latina: ALADI, SML y SUCRE (LC/L.3692), 2013.

244. A regional reserve fund for Latin America (LC/L.3703), 2013.

243. Weak expansions: A distinctive feature of the business cycle in Latin America and the Caribbean (LC/L.3656), 2013.

242. Dos décadas de cambios en la equidad en el sistema de salud colombiano: 1990-2010 (LC/L.3512), 2012.

241. Conglomerados de desarrollo en América Latina y el Caribe: una aplicación al análisis de la distribución de la Ayuda Oficial al Desarrollo (LC/L.3507), 2012.

240. Reforma al sistema de pensiones chileno (LC/L.3422), 2011.

239. Equidad y solvencia del sistema de salud de cara al envejecimiento: El caso de Costa Rica (LC/L.3370), 2011.

238. La protección social en Chile, El Plan AUGE: Avances y desafíos (LC/L.3348), 2011.

237. El caso de las cajas de ahorro españolas en el período 1980-2010 (LC/L.3300-P), N ${ }^{0}$ de venta S.11.II.G.21 (US\$10,00), 2011.

236. The European investment bank and SMEs: key lessons for Latin America and the Caribbean, (LC/L.3294-P), sales $\mathrm{N}^{\mathrm{O}}$ E.11.II.G.16 (US\$10, 00), 2011.

235. El futuro de las microfinanzas en América Latina: algunos elementos para el debate a la luz de las transformaciones experimentadas (LC/L.3263-P), $\mathrm{N}^{\mathrm{o}}$ de venta S.10.II.G.68 (US\$10,00), 2010.

234. Re-conceptualizing the International aid structure: recipient-donor interactions and the rudiments of a feedback mechanism (LC/L.3262-P), $\mathrm{N}^{\mathrm{o}}$ de venta S.10.II.G.67 (US\$10,00), 2010.

233. Financiamiento a la inversión de las pymes en Costa Rica (LC/L.3261-P), $\mathrm{N}^{\mathrm{o}}$ de venta S.10.I.G.66 (US\$10,00), 2010.

232. Banca de desarrollo en el Ecuador (LC/L.3260-P), $\mathrm{N}^{0}$ de venta S.10.II.G.65 (US\$10,00), 2010.

231. Política cambiaria y crisis internacional: el rodeo innecesario (LC/L.3259-P), $\mathrm{N}^{0}$ de venta S.10.II.G.64 (US\$10,00), 2010.

230. Desenvolvimento financiero e crescimento econômico: teoria e evidência (LC/L.3257-P), N ${ }^{0}$ de venta S.10.II.G.62 (US\$10,00), 2010. 

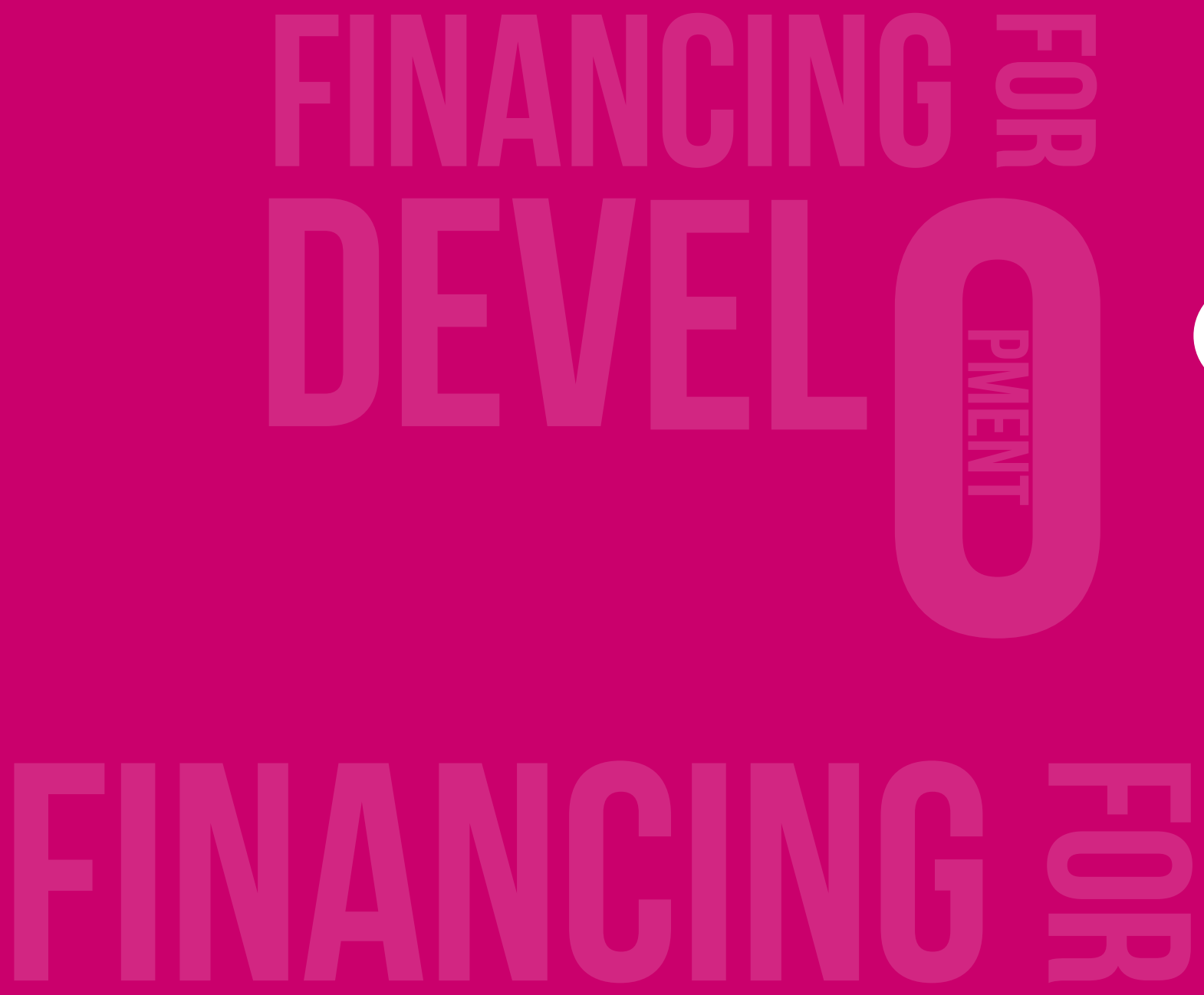

\section{FINANCING FOR DEVELOPMENT}

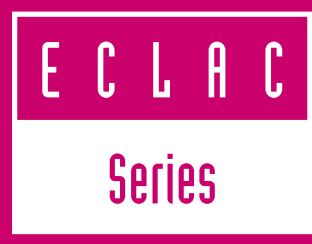

ECONOMIC COMMISSION FOR LATIN AMERICA AND THE CARIBBEAN

COMISIÓN ECONÓMICA PARA AMÉRICA LATINA Y EL CARIBE

www.eclac.org 